Universidade de São Paulo

Faculdade de Medicina de Ribeirão Preto

Custo-efetividade das ferramentas de captação

LEONARDO SCALON DE OLIVEIRA

Ribeirão Preto

2018 
LEONARDO SCALON DE OLIVEIRA

\section{Custo-efetividade das ferramentas de captação}

Dissertação de Mestrado apresentada ao Programa de Pós-Graduação em Hemoterapia e Biotecnologia para a obtenção do título de Mestre em Ciências.

Área de Concentração: Hemoterapia.

Orientador: Prof. Dr. Edson Zangiacomi Martinez

Ribeirão Preto 
Autorizo a reprodução e divulgação total ou parcial deste trabalho, por qualquer meio convencional ou eletrônico, para fins de estudo e pesquisa, desde que citada a fonte.

\section{Catalogação da publicação}

Faculdade de Medicina de Ribeirão Preto

De Oliveira, Leonardo Scalon

Custo-efetividade das ferramentas de captação. Ribeirão Preto, 2018.

58 p.: il.; $30 \mathrm{~cm}$.

Dissertação de Mestrado apresentada à Faculdade de Medicina de Ribeirão Preto da Universidade de São Paulo. Área de Concentração: Hemoterapia.

Orientador: Martinez, Edson Zangiacomi.

1. Hemoterapia. 2. Doação de Sangue. 3. Captação de doadores. 4. Custo-efetividade. 5.Ferramentas de captação. 


\section{Folha de Aprovação}

DE OLIVEIRA, Leonardo Scalon

Custo-efetividade das ferramentas de captação.

Dissertação de Mestrado apresentada ao Programa de Pós-Graduação em Hemoterapia e Biotecnologia para a obtenção do título de Mestre em Ciências.

Aprovado em:

Banca Examinadora

$\operatorname{Prof}(\mathrm{a}) . \operatorname{Dr}(\mathrm{a})$ : Instituição:

Julgamento: Assinatura:

$\operatorname{Prof}(\mathrm{a}) . \operatorname{Dr}(\mathrm{a})$. Instituição:

Julgamento: Assinatura:

Prof(a). Dr(a).: Instituição:

Julgamento: Assinatura: 


\section{APOIO E SUPORTE FINANCEIRO}

Trabalho desenvolvido com dados cedidos e de propriedade da Fundação Hemocentro de Ribeirão Preto. 
Dedico este trabalho a minha irmã Paty (in memoriam) por sempre ter me apoiado, ajudado e ser a melhor irmã que pudesse ter existido. Eternamente em meu coração e em minha vida... 


\section{AGRADECIMENTOS}

Agradeço a Deus pela oportunidade de viver que me foi proporcionada e a minha família Humberto, Inês, David, Patrícia e Gilcimara pelo apoio e confiança em mim depositada. Agradeço especialmente a minha noiva, Daiane, por sempre estar do meu lado, me ajudando, apoiando, ensinando, corrigindo e me fazendo feliz.

Ao meu orientador Prof. Dr. Edson Zangiacomi Martinez pela brilhante orientação, confiança, apoio e por todo o conhecimento proporcionado.

À Direção do Hemocentro de Ribeirão Preto, pelo fornecimento dos dados utilizados neste estudo.

À Coordenadora Elaine Faria Teresinha de Sousa, pelo incentivo, apoio e concessões, as quais me permitiram o cumprimento dessa jornada.

À Coordenadora Dra. Eugênia Maria Amorim Ubiali pelo incentivo, apoio, ajuda, dedicação e por todos ensinamentos proporcionados durante esses anos.

Agradeço à Ana Paula Rocha Diniz Zanelli, pelos ensinamentos, companhia e ajuda no dia a dia.

Ao Ricardo Haddad pelo poio, incentivo e ajuda.

Aos colegas Amanda, Ariane, Edineusa, Érica, Evelyn, Gustavo e Vanessa, da Gestão da Qualidade do Hemocentro RP por manterem o funcionamento esse setor nos meus momentos de ausência.

Ao Pedro Cordoba, Cristino e equipe de captadores do Posto de Coleta pela ajuda.

À Marina, da equipe de captação de doadores da Sede, pela ajuda no início deste projeto.

Aos doadores, meus sinceros agradecimentos pelas doações de sangue e respostas dos questionários.

À Secretaria da pós-graduação: Vinicius Moreno Godoi e Adriana Maria Teles Fuzaro.

À Raquel Aparecida Botelho, pela ajuda durante a jornada do mestrado.

Ao Coordenador do Programa de Pós-graduação Dimas Tadeu Covas. 
"Viver é desenhar sem borracha" Millôr Fernandes 


\section{RESUMO}

DE OLIVEIRA, L. S. Custo-efetividade das ferramentas de captação. 2018. 58f. Dissertação (Mestrado) - Faculdade de Medicina de Ribeirão Preto, Universidade de São Paulo, Ribeirão Preto, 2018.

A sociedade tem se tornado cada vez mais instruída e exigente, na qual os clientes possuem grande influência nas estruturas da organização, fazendo com que as empresas busquem aumentar a satisfação dos clientes, atendendo-os de modo a superar as suas expectativas. Nesse contexto, estão inseridos os doadores de sangue. No Brasil, a lei que regulamenta o funcionamento dos serviços hemoterápicos preconiza que a doação de sangue deve ser um ato voluntário e altruísta, no qual o doador não deve receber nenhum tipo de vantagem para realizar a doação de sangue. Segundo dados da Coordenação Geral de Sangue e Hemoderivados, no ano de 2014, a região Sudeste, na qual está concentrada a maior parte da população brasileira, registrou uma das menores taxas de doação: a cada 1.000 habitantes, apenas 17,22 \% doaram sangue. É fundamental para os hemocentros identificarem a maneira mais convincente e estimulante de convocar/captar doadores de sangue, de modo a manter os estoques suficientes, além de atender os doadores conforme suas expectativas. Portanto, o objetivo desse estudo foi avaliar qual a ferramenta de abordagem individual e coletiva que apresenta o melhor custoefetividade somado à preferência dos doadores, a qual será essencial para o aumento do número de doações. Para isso, os dados utilizados abrangem um período de 4 anos (2012 a 2015) e representam o número de candidatos à doação de sangue de duas instalações do Hemocentro RP, ambos localizados na cidade de Ribeirão Preto (Sede e Posto de Coleta). Valores- $p$ para o teste de Dickey e Fuller de estacionariedade sugerem que as séries analisadas não são estacionárias, sendo então diferenciadas, passando a apresentar $p<0,01$. Foi observado que existe correlação $(p=0,31)$ entre o número de malas diretas e o retorno dos doadores seis meses após o envio das mesmas. No Posto de Coleta, não foi constatada essa correlação. Além disso, as ferramentas para captação que trabalham com os doadores de reposição apresentaram melhores resultados, tais como as ferramentas com atendimento mais personalizado (contato telefônico) juntamente com as campanhas realizadas pelo Facebook Inc..

Palavras-chave: Hemoterapia; Doação de Sangue; Captação de doadores; Custo-efetividade; Ferramentas de captação. 


\begin{abstract}
DE OLIVEIRA, L. S. Cost-effectiveness of the tools for donors recruitment. 2018. 58f. Dissertação (Mestrado) - Faculdade de Medicina de Ribeirão Preto, Universidade de São Paulo, Ribeirão Preto, 2018.

Society has become increasingly educated and demanding, in which the customers have a strong influence on the organization's structures, causing companies to seek to increase the customer satisfaction, meeting them in a way that exceeds their expectations. In this context, blood donors are inserted. In Brazil, the law that regulates the operation of hemotherapy services recommends that blood donation should be a voluntary and altruistic act in which the donor should not receive any type of advantage in order to donate blood. According to data from the “Coordenação Geral de Sangue e Hemoderivados", in 2014, the Southeast region, where most of the Brazilian population is concentrated, had one of the lowest rates of donation: for every 1,000 inhabitants, only $17.22 \%$ donated blood. It is essential for blood centers to identify the most convincing and stimulating way to recruit and invite blood donors, to maintain sufficient stocks by serving donors according to their expectations. Therefore, the aim of this study was to evaluate which tool of individual and collective approach presents the best cost-effectiveness besides to donor preference, which will be essential for increasing the number of donations. To do so, the data cover a period of 4 years (2012 to 2015) and represent the number of candidates for blood donation from two Hemocentro RP facilities, both located in the city of Ribeirão Preto ("Sede" and "Posto de Coleta"). $p$-values for the test of Dickey and Fuller of stationarity suggest that the series analyzed are not stationary, being then differentiated, with $p<0.01$. It was observed that there is a correlation $(p=0.31)$ between the number of direct mailings and the donors return six months after sending them. No correlation was verified at the "Posto de Coleta". Moreover, recruitment tools for replacement donors present better results, such as the tools with more personalized service (telephone contact) along with the campaigns carried out by Facebook Inc..
\end{abstract}

Keywords: Hemotherapy; Blood donation; Donor recruitment; Cost-effectiveness; Recruitment tools. 


\section{LISTA DE ABREVIATURAS E SIGLAS}

- AABB: Associação Americana de Banco de Sangue e Terapia Celular;

- ABHH: Associação Brasileira de Hemoterapia e Hematologia;

- ABNT: Associação Brasileira de Normas Técnicas;

- FNQ: Fundação Nacional da Qualidade;

- FUNDHERP: Fundação hemocentro de Ribeirão Preto;

- DRS: Departamento Regional de Saúde;

- CGSH: Coordenação Geral de Sangue e Hemoderivados;

- TCLE: Termo de Consentimento Livre e Esclarecido. 


\section{LISTA DE FIGURAS}

Figura 1. Unidades e regiões de abrangência do Hemocentro de Ribeirão Preto. 4

Figura 2. Demonstração de uma série estacionária, em que a média é independente de t e o valores oscilam em torno da média, sem tendência a aumentar ou diminuir em função de t. 13 Figura 3. Número mensal de candidatos à doação e doadores de sangue no Hemocentro Sede no período de janeiro de 2012 a dezembro de 2015. 16

Figura 4. Número de candidatos à doação e doadores de sangue registrados em cada mês no Hemocentro Sede, durante o período de Janeiro de 2012 a Dezembro de 2015.

Figura 5. Número mensal de registros de doadores de repetição, primodoadores e doações por aféreses, Hemocentro (sede), Janeiro de 2012 a Dezembro de 2015. 19

Figura 6. Número de registros de doadores de repetição, primodoadores e doações por aféreses a cada mês, Hemocentro Sede, janeiro de 2012 a dezembro de 2015. 20

Figura 7. Número mensal de candidatos à doação e doadores de sangue no Posto de Coleta, no período de janeiro de 2012 a dezembro de 2015.

Figura 8. Número de candidatos à doação e doadores de sangue registrados em cada mês, no Posto de Coleta, no período de janeiro de 2012 a dezembro de 2015. 22

Figura 9. Número mensal de registros de doadores de repetição e primodoadores, Hemocentro (Posto de Coleta), janeiro de 2012 a dezembro de 2015. 23

Figura 10. Número de registros de doadores de repetição e primodoadores a cada mês, Hemocentro (Posto de Coleta), Janeiro de 2012 a Dezembro de 2015. 24

Figura 11. Funções de autocorrelação $(\mathrm{ACF})$ para o número mensal de candidatos à doação (a), doadores (b), doadores de repetição (c), primodoadores (d) e doações por aféreses, Hemocentro Sede, Janeiro de 2012 a Dezembro de 2015.

Figura 12. Funções de autocorrelação $(\mathrm{ACF})$ para o número mensal de candidatos à doação (a), doadores (b), doadores de repetição (c), primodoadores (d) e doações por aféreses, Hemocentro (Posto de Coleta), Janeiro de 2012 a Dezembro de 2015. 28

Figura 13. Funções de correlação entre o número de mala direta enviada e o número de doadores de repetição, Janeiro de 2012 a Dezembro de 2015, no Hemocentro Sede. 29

Figura 14. Funções de correlação entre o número de mala direta enviada e o número de doadores de repetição, Janeiro de 2012 a Dezembro de 2015, no Posto de Coleta. 30 
Figura 15. Preferência dos entrevistados com relação às ferramentas de captação,

Hemocentro Sede. 31

Figura 16. Mídias sociais utilizadas pelos entrevistados, Hemocentro Sede. 32

Figura 17. Mídias sociais utilizadas pelos entrevistados, Posto de Coleta. 33

Figura 18. Preferência do entrevistados com relação às ferramentas de captação, Posto de Coleta. 33

Figura 19. Taxa de retorno, por ferramentas de captação, no Hemocentro Sede. 34

Figura 20. Taxa de retorno, por ferramentas de captação, no Posto de Coleta. 35

Figura 21. Custo-efetividade, por ferramentas de captação, no Hemocentro Sede. 36

Figura 22. Custo-efetividade, por ferramentas de captação, no Posto de Coleta. 36 


\section{LISTA DE TABELAS}

Tabela 1. Taxas de doações em 2015 nas regiões brasileiras e no Hemocentro RP. 5

Tabela 2. Taxas de doação de reposição e espontânea. 6

Tabela 3. Faixa etária dos candidatos à doação de sangue, Hemocentro Sede. 18

Tabela 4. Distribuição por cor/raça dos candidatos à doação de sangue, Hemocentro Sede. 18

Tabela 5. Faixa etária dos candidatos à doação de sangue, Posto de Coleta. 25

Tabela 6. Distribuição por cor/raça dos candidatos à doação de sangue, Hemocentro Sede. 25

Tabela 7. Valores-p para o teste de Dickey e Fuller de estacionareidade, considerando as séries temporais originais e diferenciadas. Dados do Hemocentro (sede) e Posto de Coleta, Janeiro de 2012 a Dezembro de 2015. 26 


\section{SUMÁRIO}

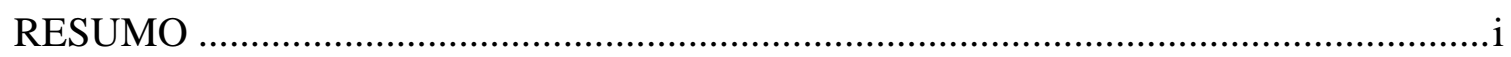

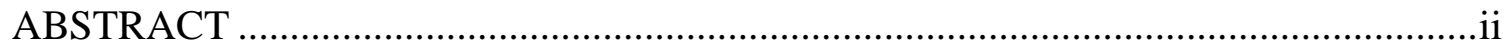

LISTA DE ABREVIATURAS E SIGLAS …..............................................................

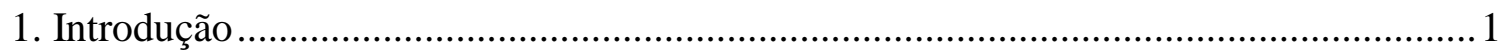

1.1 Histórico da doação de sangue no Brasil............................................................... 1

1.2 Hemorrede do Estado de São Paulo ....................................................................... 3

1.3 Caracterização do Hemocentro de Ribeirão Preto ........................................................... 3

1.4 Contexto atual da doação e transfusão de sangue no Brasil ........................................ 4

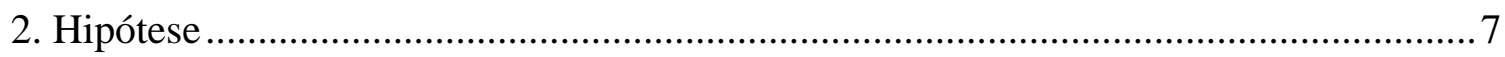

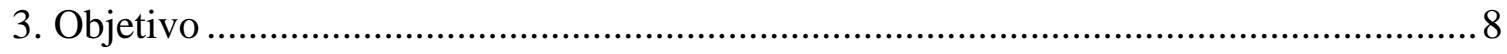

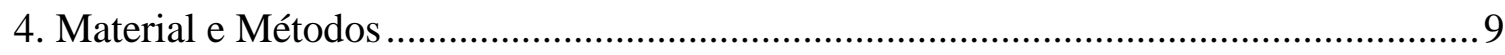

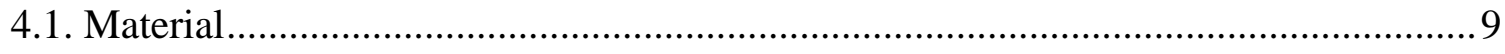

4.2. Análise Retrospectiva das ferramentas de captação ................................................ 9

4.3 Análise Prospectiva das ferramentas de captação ....................................................... 10

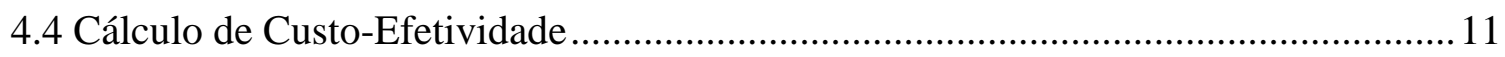

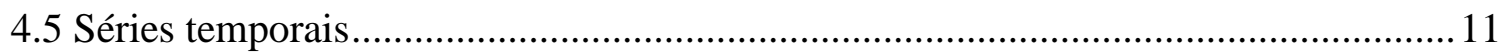

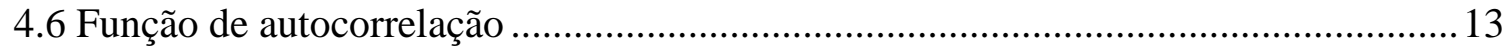

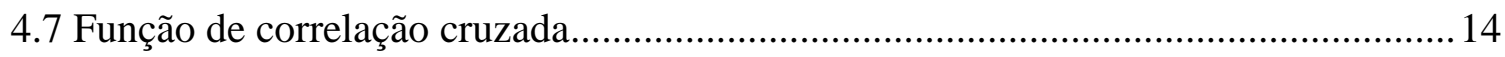

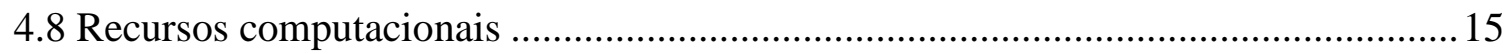

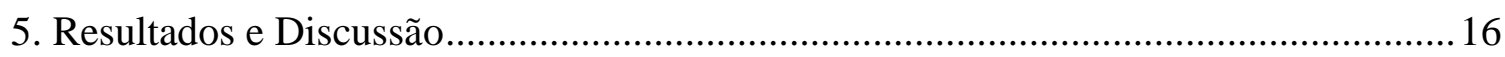

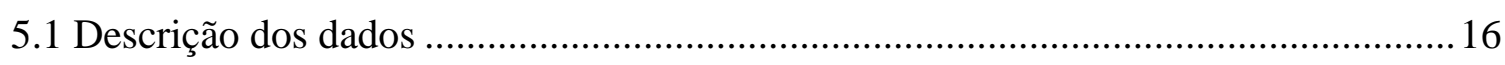

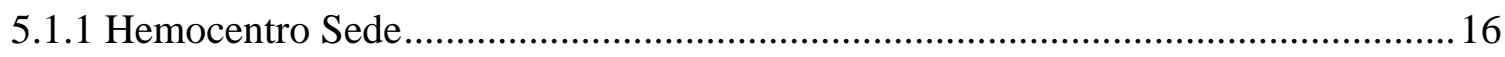

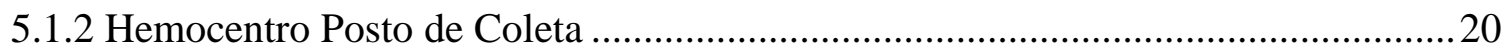

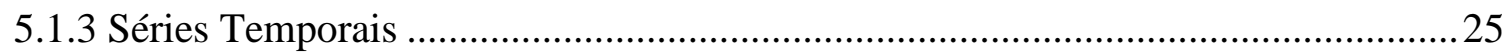

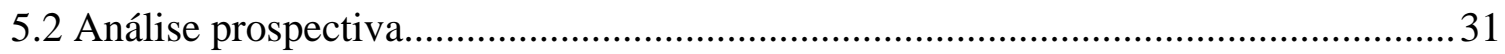

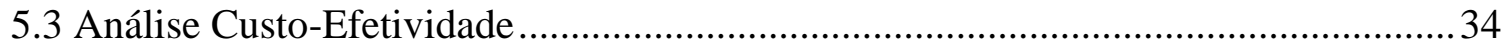

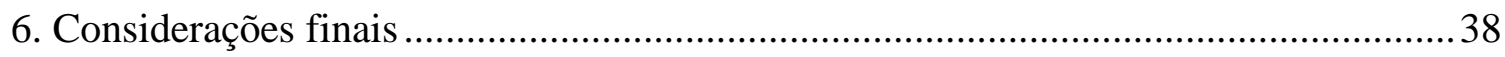

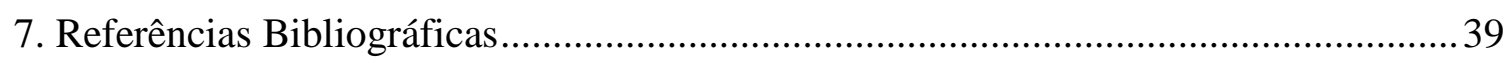

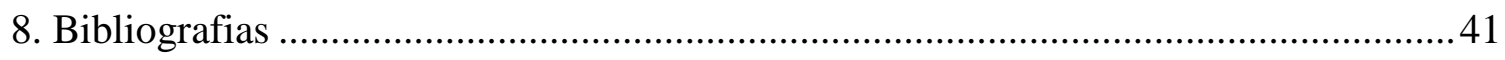

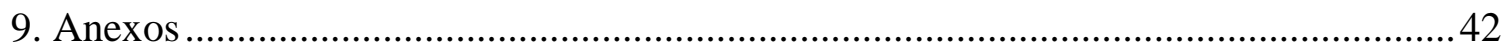

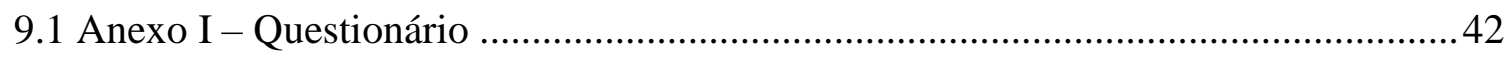

9.2 Anexo II - Termo de Consentimento Livre e Esclarecido - TCLE ............................. 43 


\section{Introdução}

\subsection{Histórico da doação de sangue no Brasil}

A Qualidade nas instituições promove uma cultura que objetiva comportamentos, atitudes, atividades e processos que agregam valor ao produto final, através da satisfação dos requisitos dos clientes e demais partes interessadas (fornecedores e órgãos reguladores, por exemplo). O contexto atual em que as organizações estão imersas é caracterizado pelas mudanças aceleradas, globalização dos mercados e surgimento do conhecimento como recurso principal. A qualidade está além da satisfação do cliente, impactando sobre a reputação das instituições (ABNT, 2015).

Nesse sentido, a sociedade tem se tornado mais instruída e exigente, fator que torna os clientes cada vez mais influentes, forçando as organizações atenderem aos critérios legais, ou não, empenhando-se em exceder as expectativas dos clientes, e assim, proporcionando experiências de excelência para os mesmos e mantendo-os fidelizados (FNQ, 2015). Nesse contexto, são inseridos os doadores de sangue voluntários.

No Brasil até a década de 1980, a doação de sangue foi marcada pela renumeração aos doadores. A primeira lei que promoveu a doação de sangue no Brasil foi a Lei Federal 1.075/50, que ilustrava seu benefício. Esse fato é evidenciado no Artigo $1^{\circ}$ da referida lei, estabelecendo que "Será consignada com louvor na folha de serviço de militar, de funcionário público civil ou de servidor de autarquia, a doação voluntária de sangue”. Assim enraíza-se na população os interesses pessoais, familiares e comerciais para doação de sangue (BRASIL, 2015).

Após a década de 1980, com o surgimento da AIDS e a proliferação das doenças transmissíveis por transfusão sanguínea, surgiram preocupações com a segurança e qualidade do sangue e componentes a serem transfundidos. O medo do sangue fez com que as autoridades sanitárias de vários países, inclusive do Brasil, se esforçassem para eliminar a possibilidade de doações renumeradas e benefício diretos e/ou indiretos para os doadores de sangue (BRASIL, 2015).

Posteriormente, a Constituição Federal de 1988 elimina a doação de sangue renumerada, fato claramente definido no Artigo $199^{\circ}$, parágrafo $4^{\circ}$ : "bem como a coleta, processamento e transfusão de sangue e seus derivados, sendo vedado todo tipo de comercialização" (BRASIL, 1988). 
Atualmente, a lei que regulamenta a prática hemoterápica no Brasil é a Portaria de Consolidação $\mathrm{n}^{\circ}$ 05, de 3 de Outubro de 2017 , no qual seu artigo $2^{\circ}$, parágrafo $2^{\circ}$, preconiza que "A manutenção de toda a cadeia produtiva do sangue depende dos valores voluntários $e$ altruístas da sociedade para o ato da doação", e no seu artigo $30^{\circ}$ define que a "doação de sangue deve ser voluntária, anônima e altruísta, não devendo o doador, de forma direta ou indireta, receber qualquer remuneração ou benefício em virtude da sua realização" (BRASIL, 2017). Segundo essa portaria, é caracterizado como pessoa apta a doar sangue aquela cujos dados pessoais, condições clínicas, laboratoriais e epidemiológicas, encontram-se em conformidade com os critérios de aceitação vigentes para a doação de sangue.

A Portaria de Consolidação $\mathrm{n}^{\circ} 5$ faz distinção entre os doadores de repetição, esporádicos e de primeira vez (BRASIL, 2017). É definido como doador de repetição o indivíduo que realiza duas ou mais doações em um período de 12 meses, enquanto o esporádico é aquele doador que repete a doação em um prazo superior a 12 meses. O doador de primeira vez é considerado o indivíduo que doa pela primeira vez naquele serviço. Para discutirmos as questões que tangem o número de doadores de sangue é importante definir o que é considerado um doador inapto definitivamente e aquele que é inapto temporariamente. O doador inapto definitivo nunca poderá doar sangue para outra pessoa, podendo apenas em alguns casos, doar sangue, enquanto paciente, para si mesmo (doação autóloga). Já aquele indivíduo considerado inapto temporário é o doador que se encontra impedido de doar sangue para outra pessoa, por um período de tempo determinado, podendo, se necessário, realizar doação autóloga (BRASIL, 2017).

Considerando as definições de doadores de sangue, os critérios de seleção do doador e a obrigação de realizar a coleta sem causar nenhum prejuízo ao doador, os serviços hemoterápicos encontram grande dificuldade em captar doadores de sangue. Apesar da doação de sangue ser fundamental para a manutenção da vida de muitas pessoas, captar doadores de é uma rotina complexa e muitas vezes individualizada. É necessário utilizar técnicas que proporcionem o entendimento e o conhecimento dos aspectos culturais, sociais, políticos e econômicos que envolvem e encorajam a doação de sangue voluntária e altruísta.

A identificação e adoção da ferramenta mais adequada para estimular parte da população à doação e o atendimento das expectativas dos clientes aumentam a probabilidade de retorno desses doadores voluntários. Assim como identificar o "outro em seu contexto" não é uma 
atividade fácil, eleger a ferramenta de captação mais adequada também é um exercício complexo.

\subsection{Hemorrede do Estado de São Paulo}

A Hemorrede do Estado de São Paulo foi criada em 1999 pelo Decreto no 32.849, de 23 de janeiro de 1991. O objetivo dessa Hemorrede é desenvolver ações especificadas no Plano Nacional do Sangue e Hemoderivados e pelo Programa Estadual de Hematologia-Hemoterapia da Secretaria de Estado da Saúde de São Paulo. O Estado de São Paulo, diferentemente dos demais estados do Brasil, possui uma Hemorrede composta por seis Hemocentros considerados “coordenadores regionais": Fundação Pró-Sangue, Hemocentro de Campinas, Hemocentro de Marília, Hemocentro de Botucatu, Hemocentro de São José do Rio Preto e Hemocentro de Ribeirão Preto, além do Instituto Butantan, inserido à Hemorrede de São Paulo pelo Decreto ${ }^{\circ}$ 62.766, de 4 de agosto de 2017 (SÃO PAULO, 1991).

\subsection{Caracterização do Hemocentro de Ribeirão Preto}

O Hemocentro de Ribeirão Preto está localizado no interior do estado de São Paulo e possui 14 unidades no estado. Há cinco núcleos (Araçatuba, Fernandópolis, Franca, Presidente Prudente e Taubaté); três unidades (Batatais, Bebedouro e Olímpia); quatro Agências Transfusionais (Agência Transfusional Hospital das Clínicas - Unidade Campus; Agência Transfusional Hospital das Clínicas - Unidade de Emergência; Agência Transfusional MATER e Agência Transfusional Jales); e um Posto de Coleta e a Sede, ambos localizados em Ribeirão Preto (HEMOCENTRO RP, 2016). A Figura 1 representa suas unidades e as respectivas regiões de abrangência, que atualmente contam com aproximadamente 5 milhões e 200 mil pessoas. O Hemocentro de Ribeirão Preto é uma fundação (FUNDHERP) sem fins lucrativos, a qual foi criada em 1990 com o objetivo de administrar a rede de atendimento do Centro Regional de Hemoterapia (CRH), um departamento do Hospital das Clínicas da Faculdade de Medicina de Ribeirão Preto ligada à Universidade de São Paulo. O Hemocentro RP possui certificação ISO 9001:2008, sendo a primeira certificação obtida em 1999. Além dessa certificação, possui Acreditação AABB Banco de Sangue e Serviço de Transfusão e Terapia Celular desde 2003. AABB é uma instituição norte americana que elabora padrões para serviços de coleta, transfusão e terapia celular. Essa instituição possui um programa de Acreditação da AABB tem 
como objetivo aumentar a qualidade da coleta de sangue, processamento, distribuição e testas realizados nas amostras de sangue. Quanto a rotina, no ano de 2015, por exemplo, foram coletadas 93 mil bolsas, atendendo aproximadamente cerca de 110 Hospitais Conveniados, com aproximadamente 93 mil transfusões (HEMOCENTRO, 2015).

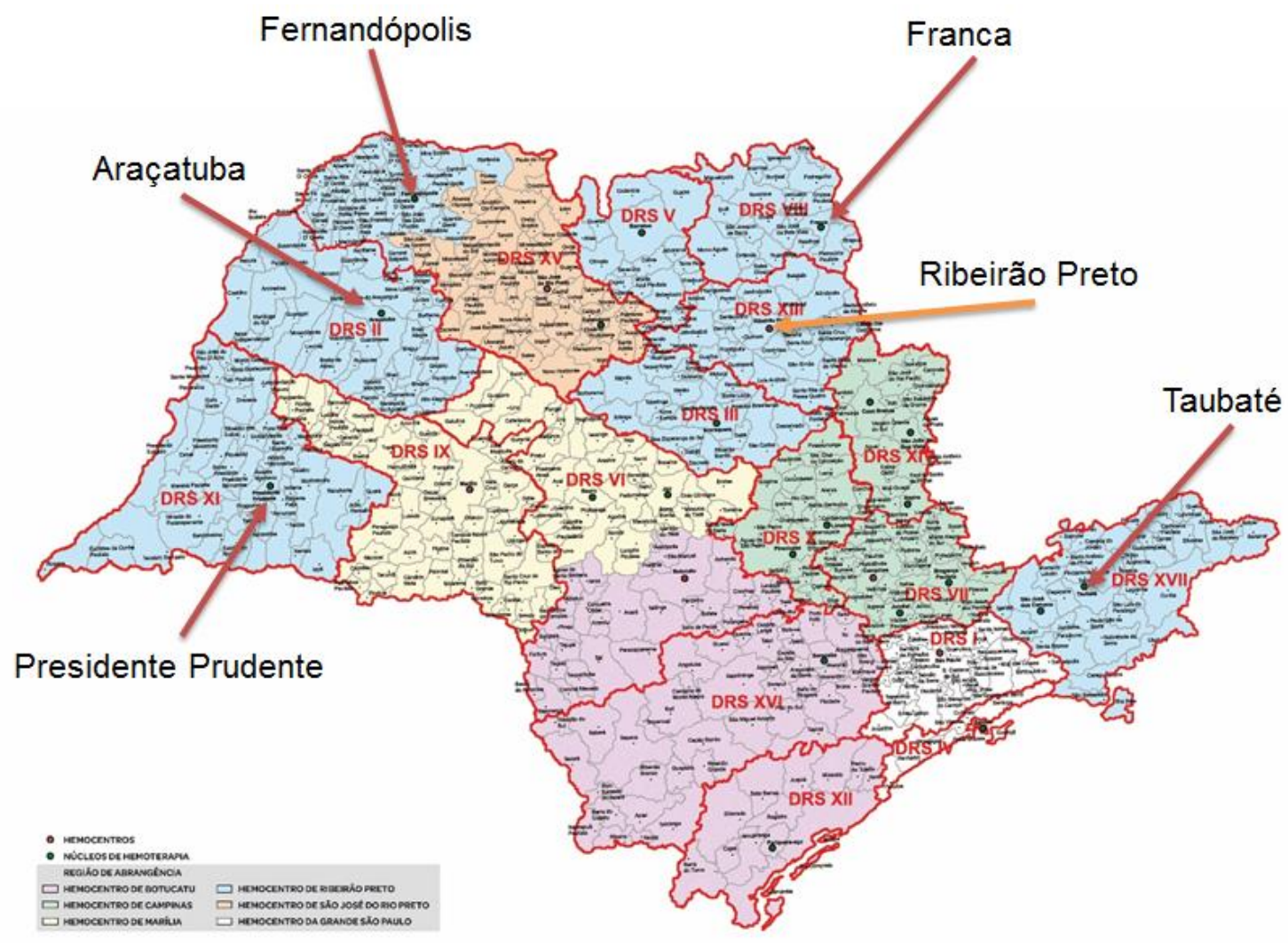

Figura 1. Unidades e regiões de abrangência do Hemocentro de Ribeirão Preto.

\subsection{Contexto atual da doação e transfusão de sangue no Brasil}

Os Hemocentros do Brasil enfrentam situações caóticas por terem estoques de sangue e componentes reduzidos, devido principalmente às dificuldades de captação de doadores (MINISTÉRIO DA SAÚDE, 2013).

Segundo dados da Coordenação Geral de Sangue e Hemoderivados, no ano de 2014, a região Sudeste apresentou uma das menores taxas de doação a cada 1.000 habitantes, com uma taxa de apenas 17,22. Já a região Centro-Oeste apresentou a maior taxa de doação, com 28,24. Entretanto, segundo os dados apresentados nesse mesmo relatório, a região Sudeste é aquela que apresenta maior população, com 85.115.623 habitantes, sendo que a região Centro-oeste apresenta a menor população do país com 15.219.608 habitantes. O número de doações na 
região Centro-oeste foi de 429.747, sendo que o total de transfusões nessa mesma região foi de 297.177. Já na região Sudeste, o total de doações foi de 1.465.902, sendo o total de transfusões, igual a 1.438.405 (MINISTÉRIO DA SAÚDE, 2015). Se considerarmos que o número de doações não significa que aquela doação pôde ser utilizada em uma transfusão, fica evidente que o número de doações na região Sudeste necessita ser elevado. A Tabela 1 exibe as taxas de doações nas diferentes regiões do Brasil. Para isso, identificar o contexto e a diversidade de experiências dos outros indivíduos facilita o convencimento e o encorajamento à doação de sangue (FROTA, 2005). Segundo LOURENÇON et. al. (2011), apenas $32 \%$ dos doadores de primeira vez retornam ao Hemocentro RP para efetuarem outras doações, em um período de 5 anos.

Tabela 1. Taxas de doações em 2015 nas regiões brasileiras e no Hemocentro RP.

\begin{tabular}{ccccc}
\hline \multicolumn{5}{c}{ Dados de 2015 } \\
\hline Região & Coleta & População & Taxa/1.000 hab. & Total de Transfusão \\
\hline Centro Oeste* $^{*} 410.879$ & 15.442 .232 & 26,61 & 295.184 \\
Nordeste* $^{*}$ & 894.097 & 56.560 .081 & 15,81 & 735.190 \\
Norte* & 244.032 & 17.472 .636 & 13,97 & 159.576 \\
Sudeste* & 1.487 .296 & 85.745 .520 & 17,35 & 1.471 .544 \\
Sul* & 684.563 & 29.230 .180 & 23,42 & 724.157 \\
& & & & 819.159 \\
São Paulo * & 878.327 & 44.396 .484 & 19,78 & 101.420 \\
\hline
\end{tabular}

*Brasil. Ministério da Saúde. Secretaria de Atenção à Saúde. Departamento de Atenção Especializada e Temática. Caderno de informação : sangue e hemoderivados : dados de 2015 [recurso eletrônico] / Ministério da Saúde, Secretaria de Atenção à Saúde, Departamento de Atenção Especializada e Temática. - Brasília: Ministério da Saúde, 2017.

**Relatório de gestão 2015. Hemocentro RP. Sem o Núcleo de Taubaté

Além disso, as doações de reposição, que segundo a Portaria de Consolidação $\mathrm{N}^{\circ} 5$ é definida como a doação para atender à necessidade de um paciente, não é o modelo de doação ideal. Segundo FROTA (2005), essas doações constituem uma ideia de obrigação, em que as famílias não medem esforços para angariar doadores, podendo até mesmo oferecer benefícios em troca das doações. Os doadores de repetição são os mais adequados, pois estão comprometidos com a doação, o que representa maior quantidade e qualidade no sangue doado. Na Tabela 2 estão representadas as taxas de doação de reposição e espontânea. 
Tabela 2. Taxas de doação de reposição e espontânea.

\begin{tabular}{|c|c|c|c|c|c|c|c|}
\hline & Norte & $\begin{array}{c}\text { Centro - } \\
\text { Oeste }\end{array}$ & Nordeste & Sudeste & Sul & Sede & PC \\
\hline $\begin{array}{l}\text { Motivação da } \\
\text { doação }\end{array}$ & Total & Total & Total & Total & Total & Total & Total \\
\hline Espontânea & $55,69 \%$ & $79,62 \%$ & $49,85 \%$ & $66,58 \%$ & $76,03 \%$ & $67,34 \%$ & $81,55 \%$ \\
\hline Reposição & $44,31 \%$ & $20,37 \%$ & $50,14 \%$ & $33,39 \%$ & $23,94 \%$ & $31,90 \%$ & $18,45 \%$ \\
\hline \multicolumn{6}{|c|}{$\begin{array}{l}\text { Brasil. Ministério da Saúde. Secretaria de Atenção à Saúde. Departamento de Atenção Especializada e } \\
\text { Temática. Caderno de informação : sangue e hemoderivados : dados de } 2015 \text { [recurso eletrônico] / } \\
\text { Ministério da Saúde, Secretaria de Atenção à Saúde, Departamento de Atenção Especializada e } \\
\text { Temática. - Brasília: Ministério da Saúde, } 2017 \text {. }\end{array}$} & \multicolumn{2}{|c|}{$\begin{array}{l}\text { Dados de } 2015 \text { - Hemocentro } \\
\text { RP }\end{array}$} \\
\hline
\end{tabular}

A doação de sangue é um ato altruísta que salva e possibilita a manutenção da vida de muitas pessoas. Segundo dados da Coordenação Geral de Sangue e Hemocomponentes (CGSH), em 2014 foram realizadas 3.293.934 transfusões. Entretanto, apenas a solidariedade e o altruísmo não estimulam as doações de sangue capazes de suprir a demanda. Conforme apresentado por MARTINEZ (2010), o ato da doação é influenciado não apenas por campanhas, mas também pela exposição do doador às informações de mídias e outros eventos, subsidiando a necessidade de identificar qual é a ferramenta de convocação/convite que mais agrada os doadores e candidatos à doação. Para isso, é necessário o planejamento das atividades da captação, possibilitado pela identificação de técnicas de abordagens individuais e coletivas adequadas, com melhor custo-efetividade e que sejam determinantes no encorajamento e convencimento à doação de sangue. 


\section{Hipótese}

Apenas o altruísmo e a boa vontade não levam uma parte efetiva da população a realizar doação de sangue. Portanto, é preciso identificar o contexto e a melhor forma de abordagem de doadores, convidando-os e estimulando-os da maneira mais adequada à realizar a doação de sangue voluntária, é essencial para elevar o número de doações e manter fidelizados aqueles doadores que já realizaram uma ou mais doações. Dessa maneira, planejar e utilizar as ferramentas mais efetivas em números de encorajamento e convencimento à doação versus custo financeiro é fundamental para manter o estoque de hemocomponentes estável e suficiente, elevando também o número dos doadores de repetição. 


\section{Objetivo}

O presente estudo teve como objetivo principal avaliar qual a ferramenta de abordagens individual e coletiva que apresenta o melhor custo-efetividade somado à preferência dos doadores.

Os objetivos específicos foram:

- Analisar os números de doações no período de 01 de Janeiro de 2012 a 31 de Dezembro de 2015, identificando as técnicas de abordagens individuais e coletivas utilizadas nos períodos com maiores e menores números de doações;

- Avaliar qual a técnica de abordagem preferencial dos doadores que foram convidados e que retornaram para realizar novas doações. 


\section{Material e Métodos}

\subsection{Material}

Para a realização desse estudo foram utilizados dados referentes ao número total de candidatos à doação e ao número de doadores que compareceram no Hemocentro RP, campus e Posto de Coleta (centro), durante o período de 2012 a 2015, bem como as ferramentas de captação de doadores empregadas pela equipe de captação de doadores, no período descrito acima.

Os candidatos à doação de sangue foram classificados e definidos conforme apresentado na Portaria de Consolidação $\mathrm{n}^{\circ} 5$.

\subsection{Análise Retrospectiva das ferramentas de captação}

Os números de candidatos à doação e total de doações foram divididos anualmente e agrupados mensalmente. Os picos de candidatos à doação e de doadores, superior e inferior, foram identificados. Os candidatos à doação, os doadores de sangue total e por aférese foram considerados e analisados separadamente.

Para esses picos, as ferramentas de captação de doadores empregadas pela equipe foram identificadas e, se possível, agrupadas de acordo com o meio utilizado para a convocação/captação. As ferramentas de captação empregadas também foram analisadas separadamente para doações de sangue total e por aférese. Os meios considerados para convocação/captação foram e-mail, telefone, mensagem de celular, panfletagem, campanhas em televisão, campanhas em redes sociais (Facebook Inc. e Instagram), e palestras. Foram consideradas as campanhas nos diversos meios de comunicação que foram oficiais e registradas nos documentos internos do Hemocentro RP.

Os candidatos à doação de sangue, durante o cadastro, foram questionados sobre o motivo/estímulo da vinda ao hemocentro. Diante da resposta, uma das opções de ferramentas de captação foi assinalada no sistema. Nesse sentido, as ferramentas de captação estudadas na análise retrospectiva foram:

- Mala direta - Doadores: cartas enviadas aos doadores aptos em doação anterior e que satisfazem todos os demais critérios legais para doação de sangue. Essa ferramenta não é utilizada para doadores de primeira vez. 
- Mala direta - Pacientes: cartas enviadas aos familiares que estão internados nos hospitais conveniados do Hemocentro RP.

- E-mails: enviados aos doadores aptos em doação anterior e que satisfazem todos os demais critérios legais para doação de sangue, além de possuírem e-mail cadastrado no sistema. Essa ferramenta não é utilizada para doadores de primeira vez.

- Torpedos - SMS: enviados aos doadores aptos em doação anterior e que satisfazem todos os demais critérios legais para doação de sangue. Essa ferramenta não é utilizada para doadores de primeira vez. Além disso, tal mensagem é enviada somente para uma determinada operadora.

- Telefonema - doadores: ligações para grupos de doadores com grupo sanguíneo específico e que irão realizar coletas de hemocomponentes por aférese. Além do tipo sanguíneo, os doadores que recebem esses telefonemas devem satisfazer os demais critérios legais.

- Abordagens em Fila de Visita: abordagens coletivas de familiares realizadas por profissional do setor de captação nos ambientes de espera para visitas a pacientes internados nos hospitais conveniados.

- Telefonema - Transfundidos: realizado para familiares de pacientes que receberam sangue/hemocomponentes nos hospitais conveniados, cujo sangue/hemocomponentes foram distribuídos pelo Hemocentro RP.

- Campanhas: realizadas mensalmente utilizando a rede social Facebook Inc., nas quais são elaborados cartazes temáticos para estimular a doação de sangue.

- Mobilizado: inserções realizadas pelas emissoras de televisão.

- Outdoor: abordagem elaborada pelo Hemocentro RP em convênio com outras empresas. Os candidatos à doação de sangue também foram questionados sobre a cor de pele, cuja resposta foi inserida no sistema.

\subsection{Análise Prospectiva das ferramentas de captação}

Foi realizada uma análise prospectiva das ferramentas de captação mais adequadas para o convite/convocação de doadores. Para isso, foi utilizado um questionário (Anexo I) que foi entregue aos candidatos à doação de sangue que compareceram no Hemocentro RP ou no Posto 
de Coleta. Os questionários que apresentaram mais de duas respostas na questão referente à ferramenta de captação foram considerados inválidos. Já os questionários sem resposta para esta pergunta foram considerados em branco. Os questionários foram analisados de acordo com o local de comparecimento, sendo seu objetivo identificar qual a ferramenta preferida pelos candidatos à doação de sangue para serem convocados/convidados à doação de sangue. Foi necessária a aplicação do Termo de Consentimento Livre e Esclarecido - TCLE (Anexo II), uma vez que foram obtidas informações dos candidatos à doação de sangue, aprovado pelo CEP HCRP E FMRP em 25/10/2016 com o código CAAE 59658516.9.0000.5440.

\subsection{Cálculo de Custo-Efetividade}

Para a estimativa/cálculo do custo financeiro para cada forma de convocação/convite dos doadores, foram utilizados valores atuais, independentemente do período em que foi utilizada a doação. O custo financeiro foi estimado utilizando os custos da utilização da ferramenta de captação em si, não foram inseridos custos de RH e de infraestrutura. Para a análise do custo-efetividade foi utilizada a metodologia de Custeio Baseado em Atividades $(\mathrm{ABC})$. A metodologia $\mathrm{ABC}$ tem por finalidade prover informações mais precisas sobre o custo de cada atividade envolvida nos processos produtivos e na geração de serviços.

O custo de utilização da ferramenta de captação será comparado com as análises retrospectiva e prospectiva. Será considerada como ferramenta de maior custo-efetividade àquela que apresenta menor custo financeiro com maior número de candidatos à doação de sangue captados, ou seja, com maior retorno de doadores.

\subsection{Séries temporais}

Uma série temporal pode ser definida com um conjunto de observações em diferentes instantes de tempo. No presente estudo, foram consideradas séries em que as observações são realizadas em tempos específicos e igualmente espaçados. Considerando o conjunto de instantes $T=\left\{t_{1}, \ldots, t_{n}\right\}$, a série temporal será denotada por $\left\{Y_{t}: t \in T\right\}$ ou, por simplicidade, $\left\{Y_{t}\right\}$. Ou seja, observações y em instantes $\mathrm{t}$, sendo t específicos e igualmente espaçados.

Se $\left\{Y_{t}\right\}$ é uma série temporal com variância finita, a média de $\left\{Y_{t}\right\}$ é definida por $\mu_{Y}(t)=E\left(Y_{t}\right)$, e a função de covariância de $\left\{Y_{t}\right\}$ é dada por 
$\operatorname{Cov}\left(Y_{r}, Y_{s}\right)=E\left[\left(Y_{r}-\mu_{Y}(r)\right)\left(Y_{s}-\mu_{Y}(s)\right)\right]$, em que $E 0$ denota a esperança de uma variável aleatória e $r$ e $s$ são números inteiros, de forma que $Y_{r}$ e $Y_{s}$ denotam realizações de $\left\{Y_{t}\right\}$ nos instantes $r$ e $s$, respectivamente. A covariância representa uma ideia de associação entre estas realizações, de forma que uma covariância igual a zero sugere ausência de associação. Quanto maior a covariância maior é a associação entre duas variáveis, aqui representada por $r$ e $s$. Neste estudo, as variáveis $r$ e $s$ foram as ferramentas de captação.

Uma série temporal $\left\{Y_{t}\right\}$ é chamada estacionária (ou, a rigor, fracamente estacionária) se duas condições são satisfeitas:

(a) a média $\mu_{Y}(t)$ é independente de ${ }^{t}$, e

(b) a covariância $\operatorname{Cov}\left(Y_{t}, Y_{t+k}\right)$ é independente de ${ }^{t}$ para qualquer ${ }^{k}$ inteiro.

Seja, por exemplo, uma série temporal $\left\{Y_{t}\right\}$ que descreve o número de doações mensais de sangue (y) em um período, chamado de $t$. Se a condição (a) é satisfeita, entende-se que o número de doações a cada mês oscila ao redor de uma média constante, não havendo tendência de crescimento ou decréscimo ao longo do tempo. Neste caso, podemos denotar a média $\mu_{Y}(t)$ simplesmente por $\mu_{Y}$, dado que ela não tem dependência com o tempo, ou seja, mesmo ao longo do tempo as variações do valores ficaram oscilando próximo de uma média. Entretanto, se o número de doações mensais tende a crescer ou decrescer ao longo do tempo, a média $\mu_{Y}(t)$ não é constante. Neste caso, diz-se que a série é não-estacionária. Se, por exemplo, $k=1$, a condição (b) diz que a associação que existe entre o número de doações observadas em um dado mês e o número de doações observadas em um mês anterior é constante, não importando qual o mês que está sendo considerado. Assim, interpreta-se o valor de ${ }^{k}$ como um "deslocamento" (“lag”) no tempo, como apresentado na Figura 02. Observa-se que os valores oscilam ao longo do tempo, entretanto essa oscilação fica próximo a uma média $\mu_{Y}(t)$.

O teste de hipóteses introduzido por Dickey e Fuller (1979) é comumente utilizado para se testar a estacionariedade de uma série temporal. Esse teste de hipóteses verifica se uma determinada série está satisfazendo as condições $a$ e $b$ acima descritas. Este teste tem por hipótese alternativa que a série é estacionária. Quando a série não é estacionária, é possível convertê-la em outra estacionária diferenciando-a. Isso significa que, se uma série com elementos $Y_{t}$ não é estacionária, é possível construir a nova série com elementos $\Delta Y_{t}=Y_{t}-Y_{t-1}$ 
Esta nova série possuirá um elemento a menos que a série original. É possível diferenciar uma série mais de uma vez, mas uma diferenciação comumente é suficiente para tornar a série estacionária. O pressuposto de estacionariedade é importante para a construção das funções de autocorrelação e de correlação cruzada, que estão descritas a seguir.

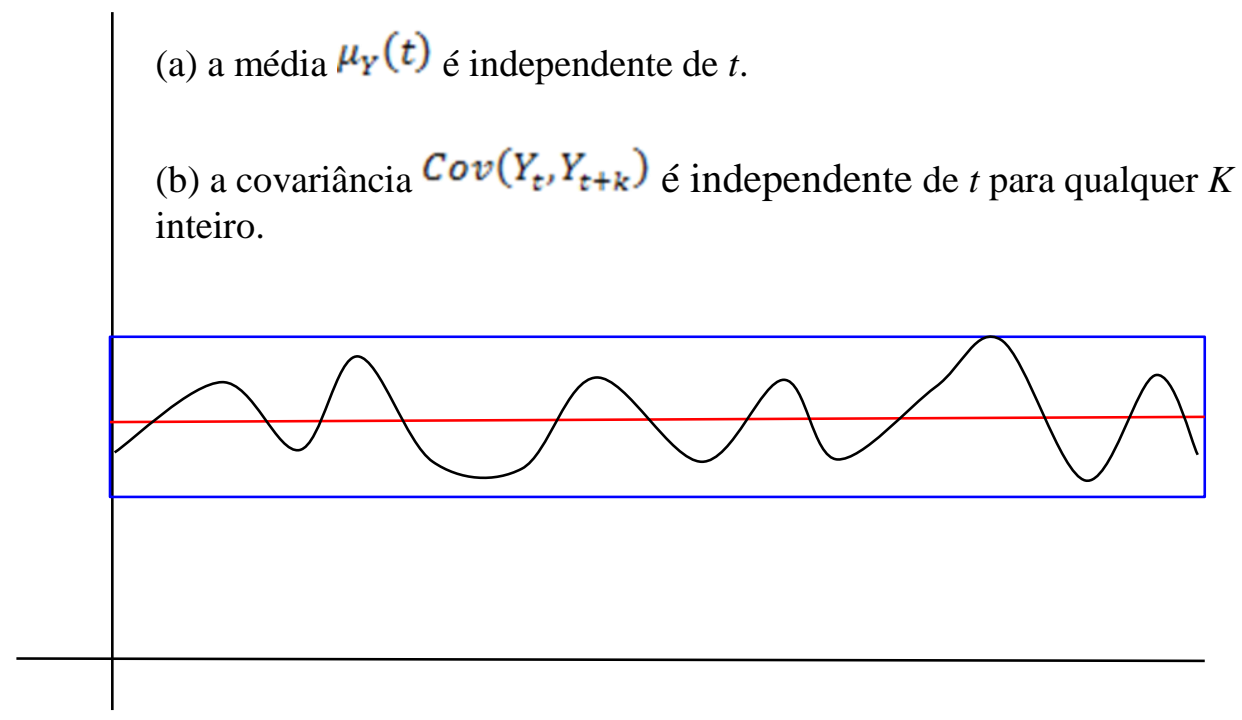

Figura 2. Demonstração de uma série estacionária, em que a média é independente de $t$ e o valores oscilam em torno da média, sem tendência a aumentar ou diminuir em função de $t$.

\subsection{Função de autocorrelação}

Dada uma série temporal $\left\{Y_{t}\right\}$, a autocorrelação é uma medida que informa o quanto o valor de uma realização de $\left\{Y_{t}\right\}$ se associa com os valores que o antecedem ou sucedem. Supondo que a série $\left\{Y_{t}\right\}$ é estacionária com média $\mu_{Y}$, a função de autocorrelação é dada por $\rho_{Y}(k)=\frac{\operatorname{Cov}\left(Y_{t}, Y_{t+k}\right)}{\sigma_{Y}^{2}}=\frac{E\left[\left(Y_{t}-\mu_{Y}\right)\left(Y_{t+k}-\mu_{Y}\right)\right]}{\sigma_{Y}^{2}}$ sendo que $E[]$ denota a esperança da expressão que está entre os colchetes, $\sigma_{Y}^{2}$ é a variância de $\left\{Y_{t}\right\}$ e ${ }^{k}$ é um número inteiro que representa um deslocamento ("lag") no tempo. Observar que $-1 \leq \rho_{Y}(k) \leq 1$, sendo que valores de $\rho_{Y}(k)$ próximos a zero indicam ausência de associação, enquanto valores próximos 
a -1 ou 1 indicam associações fortes. Em adição, para um deslocamento $k=0$, temos que $\rho_{Y}(0)=1$.

A função de autocorrelação costuma ser abreviada por ACF, de autocorrelation function. No presente estudo, a ACF foi utilizada para se investigar o comportamento das séries temporais, quanto à associação que o número de doações mensais de sangue em um dado mês (por exemplo) se associa com o número de doações observado nos meses que o antecedem. Assim, gráficos de ACF (comumente chamados "correlogramas") foram utilizados de modo

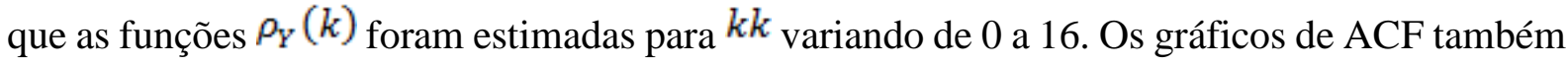
exibem intervalos utilizados para se testar a hipótese nula $H_{0}: \rho_{Y}(k)=0$ contra a hipótese alternativa $H_{A}: \rho_{Y}(k) \neq 0$ para um dado valor de $k$. Estimativas de $\rho_{Y}(k)$ que se encontram fora destes intervalos sugerem a rejeição de $H_{0}$ para o respectivo deslocamento $k$.

\subsection{Função de correlação cruzada}

A função de correlação cruzada (CCF, de cross-correlation function) entre duas séries temporais estacionárias denotadas por $\left\{X_{t}: t \in T\right\}$ e $\left\{Y_{t}: t \in T\right\}$, sendo $T=\left\{t_{1}, \ldots, t_{n}\right\}$, descreve como as observações de uma série se correlacionam com as observações de outra série, considerando um deslocamento de tamanho ${ }^{k}$. Por exemplo, é uma forma de analisar como os números mensais de doadores estão correlacionados com o número de telefonemas analisados.

A CCF é definida por:

$\rho_{X Y}(k)=\frac{\operatorname{Cov}\left(X_{t}, Y_{t+k}\right)}{\sigma_{X} \sigma_{Y}}$ sendo $\sigma_{X}$ e $\sigma_{Y}$ os desvios padrão de $\left\{X_{t}\right\}$ e $\left\{Y_{t}\right\}$, respectivamente. A CCF de uma série $\left\{X_{t}\right\}$ com ela própria se resume à função de autocorrelação. No presente estudo, foram estimadas CCF entre as séries que descrevem os números mensais de doações ou de candidatos à doação e as séries que descrevem as estratégias para a captação de doadores, considerando deslocamentos de tamanho ${ }^{k}$ variando de -13 a 13. 


\subsection{Recursos computacionais}

Para a aplicação do teste de Dickey e Fuller (1979), utilizado para se testar a estacionariedade de uma série temporal, foi utilizada a função "adf.test" da library "tseries" do programa $\mathrm{R}$ versão 3.2.2. 


\section{Resultados e Discussão}

\subsection{Descrição dos dados}

\subsubsection{Hemocentro Sede}

Os dados coletados compreenderam um período de quatro anos (2012 a 2015), período em que não foi observada a existência de tendências nas séries históricas. O número de doadores e candidatos variaram mês após mês, sem haver nenhuma autocorrelação significativa na série histórica, de acordo com gráficos de ACF (não apresentados aqui). A Figura 3 apresenta o número de candidatos à doação de sangue (linha vermelha) e o número de doadores de sangue (linha azul) do Hemocentro Sede.

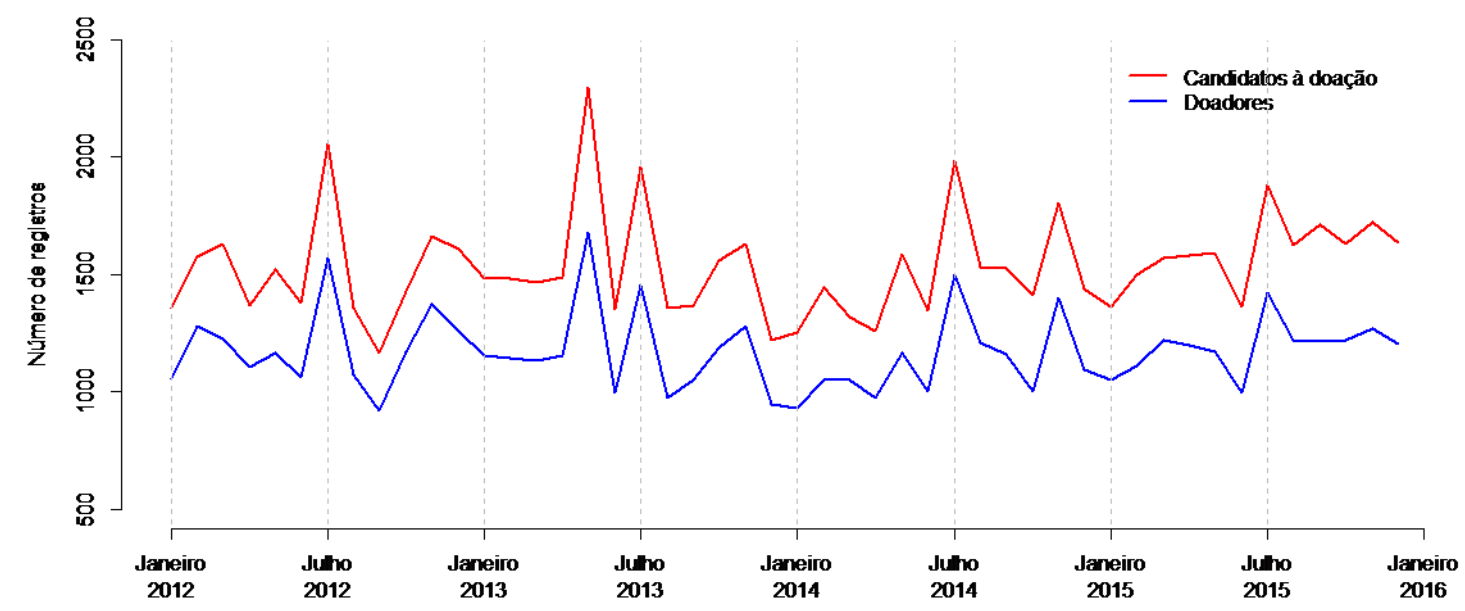

Figura 3. Número mensal de candidatos à doação e doadores de sangue no Hemocentro Sede no período de janeiro de 2012 a dezembro de 2015.

Observando a Figura 3, verificamos que o maior registro de candidatos à doação de sangue, bem como de doadores, foi no mês de maio de 2013, com 2.297 candidatos e 1.678 doadores. Observou-se que os meses de julho, de todos os 4 anos, apresentaram uma das maiores taxas de candidatos e de doadores, fato que pode ser parcialmente explicado pela realização da campanha dos bombeiros - "Bombeiro sangue bom", com ampla divulgação nas mídias e com grande participação destes profissionais.

A Figura 4 apresenta os números de candidatos (vermelho) e doadores (azul) em relação aos meses do ano. É possível observar um número elevado em maio de 2013. Não foi possível 
atribuir nenhum motivo conhecido para o número de coletas nesse mês específico, dado que este período não coincide com campanhas ou eventos realizados pela instituição.
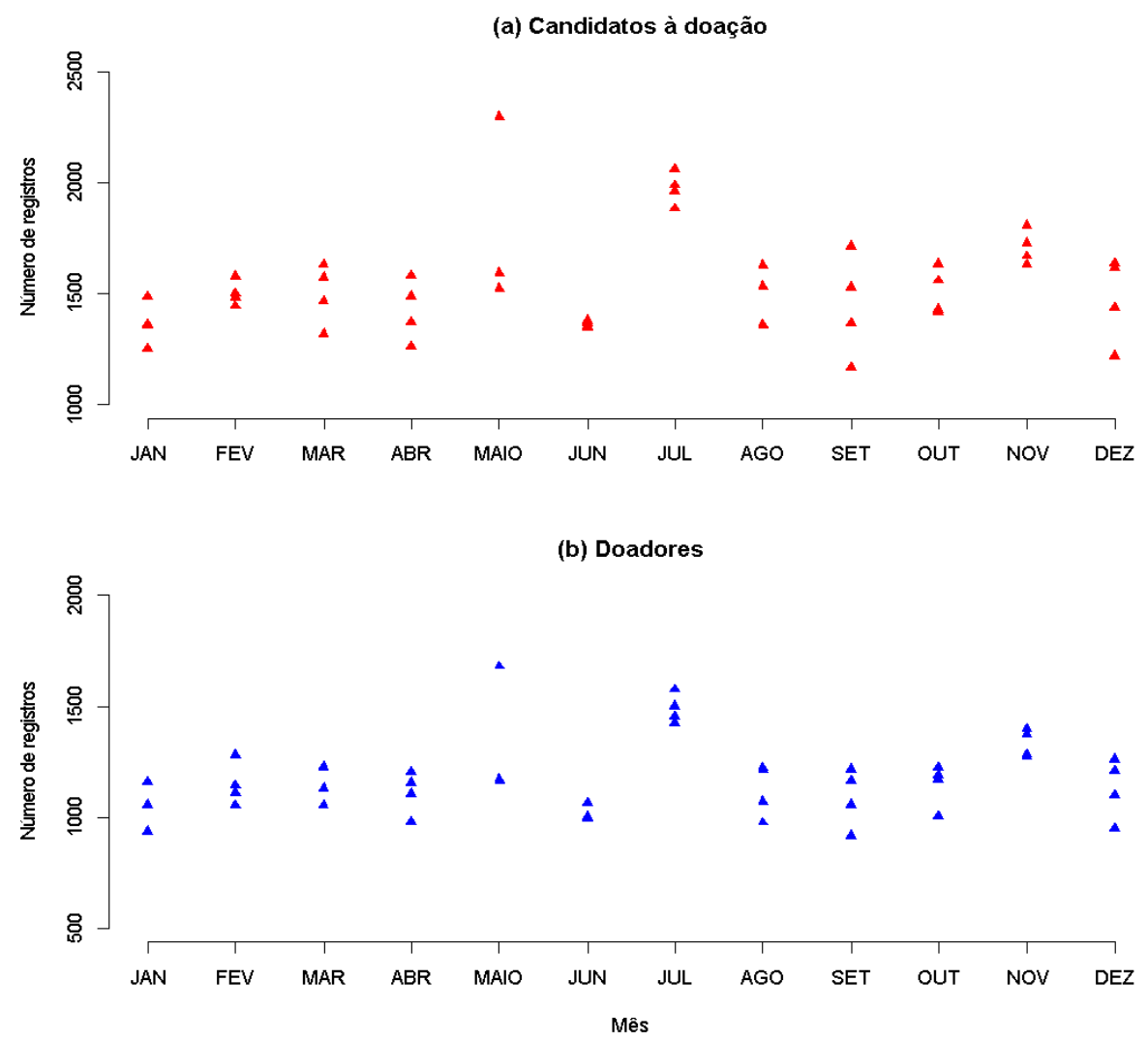

Figura 4. Número de candidatos à doação e doadores de sangue registrados em cada mês no Hemocentro Sede, durante o período de Janeiro de 2012 a Dezembro de 2015.

Em relação aos candidatos à doação de sangue, esses foram predominantemente do sexo masculino, com $64 \%(n=47.177)$, enquanto que as mulheres totalizaram $36 \%(n=26.118)$, distribuídos conforme faixa etária apresentada na Tabela $3(n=73.295)$. Observou-se ainda que mais de $75 \%$ dos doadores estão agrupados na faixa etária de 20 a 49 anos. 
Tabela 3. Faixa etária dos candidatos à doação de sangue, Hemocentro Sede.

\begin{tabular}{ccc}
\hline Masculino & Faixa etária & Feminino \\
\hline $0,29 \%$ & 65 a 69 anos & $0,07 \%$ \\
$1,29 \%$ & 60 a 64 anos & $0,43 \%$ \\
$2,78 \%$ & 55 a 59 anos & $1,08 \%$ \\
$5,08 \%$ & 50 a 54 anos & $1,78 \%$ \\
$6,42 \%$ & 45 a 49 anos & $2,59 \%$ \\
$7,86 \%$ & 40 a 44 anos & $3,17 \%$ \\
$8,68 \%$ & 35 a 39 anos & $3,99 \%$ \\
$10,43 \%$ & 30 a 34 anos & $5,57 \%$ \\
$10,42 \%$ & 25 a 29 anos & $6,64 \%$ \\
$8,01 \%$ & 20 a 24 anos & $7,20 \%$ \\
$3,10 \%$ & 16 a 19 anos & $3,11 \%$ \\
\hline
\end{tabular}

Os candidatos à doação de sangue que compareceram no Hemocentro Sede para realizar doação de sangue são classificados como de maioria de cor/raça branca com $69 \%$ ( $\mathrm{n}=50.913)$, seguidos por candidatos morenos com $22 \%(\mathrm{n}=16.033)$. Além disso, foi observado um único representante indígena. A Tabela 4 apresenta os dados relativos à cor/raça autoreferido.

Tabela 4. Distribuição por cor/raça dos candidatos à doação de sangue, Hemocentro Sede.

\begin{tabular}{ccc}
\hline \multicolumn{3}{c}{ Cor/Raça } \\
\hline Amarela & 540 & $0,74 \%$ \\
Branca & 50.913 & $69,46 \%$ \\
Indígena & 1 & $0,00 \%$ \\
Morena & 16.033 & $21,87 \%$ \\
Negra & 5.271 & $7,19 \%$ \\
Parda & 514 & $0,70 \%$ \\
Sem cor registrada & 23 & $0,03 \%$ \\
\hline
\end{tabular}

Na Figura 5, é possível observar as diferenças registradas entre os números de doadores de repetição e de primeira vez (primodoadores). Também estão representados o número de doadores de hemocomponentes por aférese. Não há grandes alterações no número desses doadores porque há um limite de doações por aférese, uma vez que tal limite é estipulado para atender a demanda sem que haja perda desses hemocompontes de especial valor. 


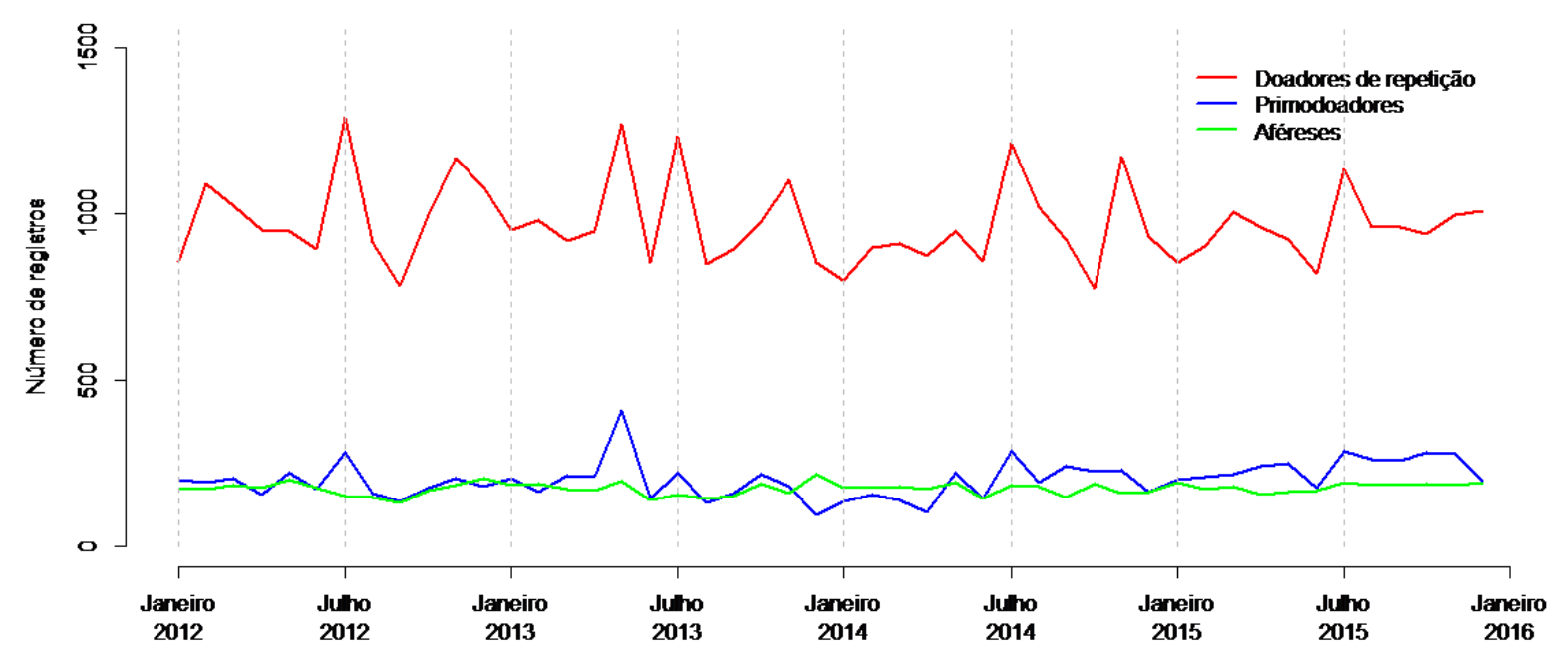

Figura 5. Número mensal de registros de doadores de repetição, primodoadores e doações por aféreses, Hemocentro (sede), Janeiro de 2012 a Dezembro de 2015.

As campanhas do Hemocentro, cujo objetivo é captar doadores novos (ou de primeira vez), são realizadas de maneira constante durante todo o ano. Na Figura 6, observa-se que o maior número de doadores de primeira vez, no Hemocentro Sede, foi em Maio de 2013, com 409 registros. Novamente, não foi possível atribuir nenhum fator específico para que em Maio houvesse recorde de registro de doadores novos. As campanhas do corpo de bombeiros, realizadas sempre nos meses de julho, foram responsáveis também pelo aumento da captação de doadores novos (doadores de primeira vez). 
(a) Doadores de repetição

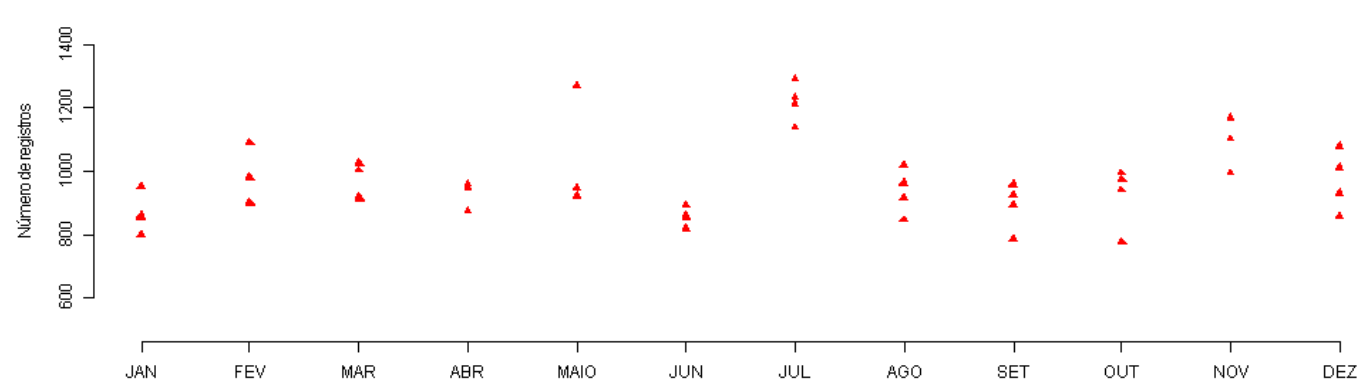

(b) Primodoadores

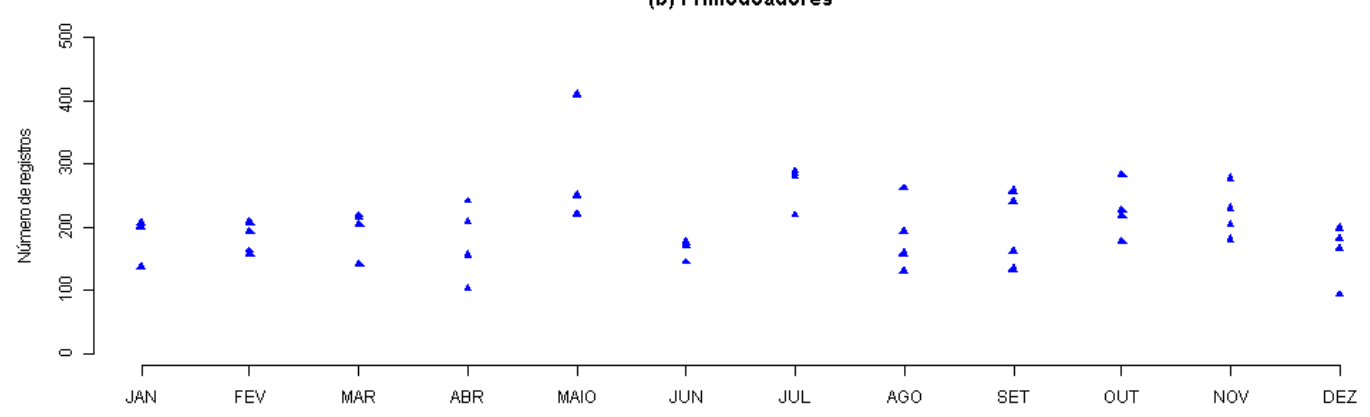

(c) Aféreses

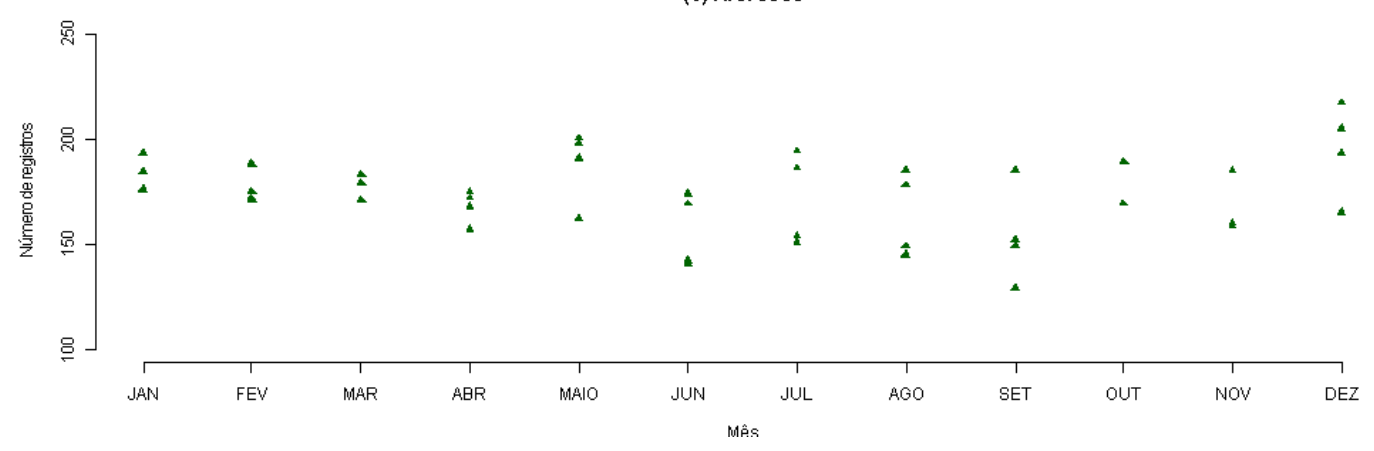

Figura 6. Número de registros de doadores de repetição, primodoadores e doações por aféreses a cada mês, Hemocentro Sede, janeiro de 2012 a dezembro de 2015.

\subsubsection{Hemocentro Posto de Coleta}

Os dados do Posto de Coleta também foram coletados e analisados para o período de quatro anos (2012 a 2015). Não foi observada nenhuma tendência em relação à série histórica. Na Figura 7 estão apresentados números de candidatos à doação e de doadores de sangue. 


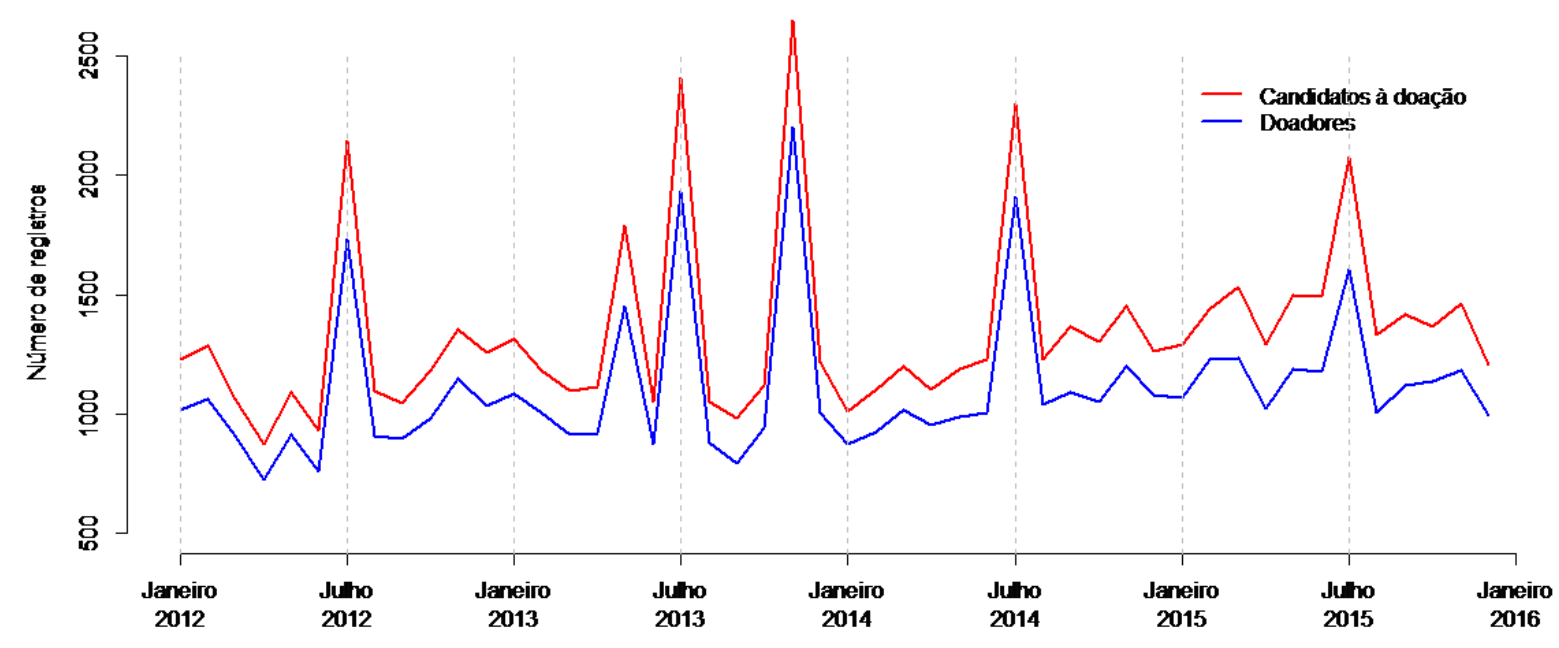

Figura 7. Número mensal de candidatos à doação e doadores de sangue no Posto de Coleta, no período de janeiro de 2012 a dezembro de 2015.

Observamos na Figura 7 que há diferença do público que frequenta esses dois locais do Hemocentro. Observou-se que a taxa de rejeição ou a diferença entre os números de candidatos e de doadores é menor quando comparada com os dados do Hemocentro Sede. Essa diferença pode ser explicada pela localização do Posto de Coleta na cidade. A região na qual está o Posto de Coleta é uma região central da cidade, com vias de acesso facilitadas. Já o Hemocentro Sede está numa região afastada da região central da cidade, próximo ao Hospital das Clínicas de Ribeirão Preto. Na análise das ferramentas de captação, essa diferença de público ficou ainda mais evidente.

No posto de coleta, o período com o menor número de candidatos (875) e doadores (721) foi em Abril de 2012. Em ambas as figuras (9 e 10), fica evidente que os números de candidatos à doação de sangue são acompanhados pelos números de doadores de sangue. É possível observar também que há uma ligeira variação desses registros entre os anos. Porém no Posto de Coleta, nos meses de novembro e dezembro, a variação entre os anos é bastante reduzida. Em geral, os gráficos revelaram dados com padrões que sugerem uma tendência em oscilar a cada mês, ou seja, um mês com aumento nas doações e o mês seguinte com queda no número de doações. Na Figura 8 são apresentados os números de candidatos e de doadores em relação aos meses do ano. 
(a) Candidatos à doação

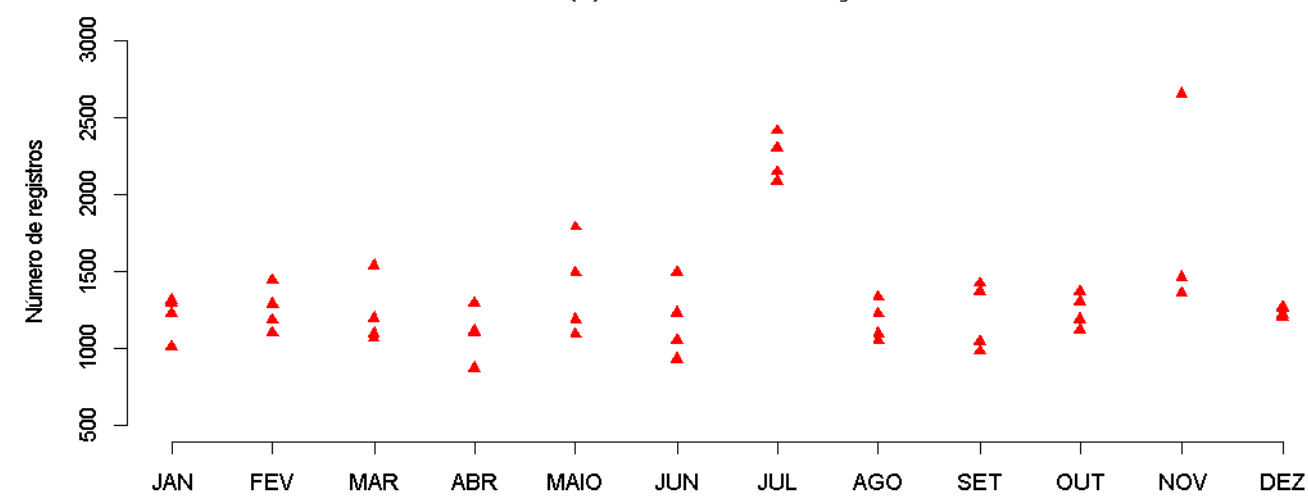

(b) Doadores

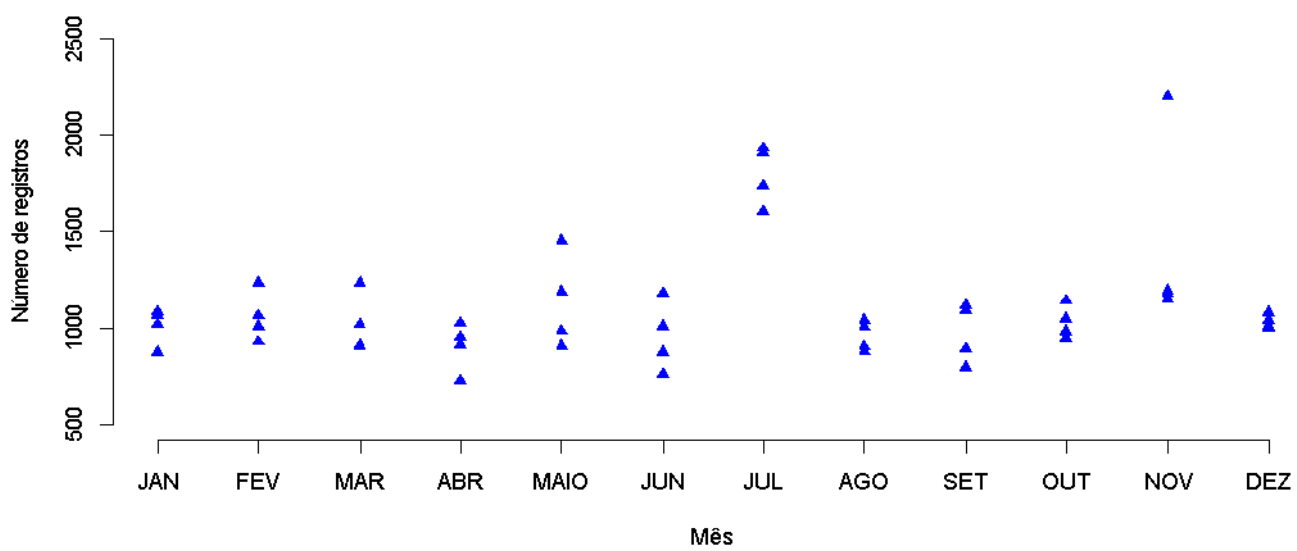

Figura 8. Número de candidatos à doação e doadores de sangue registrados em cada mês, no Posto de Coleta, no período de janeiro de 2012 a dezembro de 2015.

Nas Figuras 9 e 10, os dados de doadores de primeira vez e daqueles de repetição são apresentados para o posto de coleta. Ao contrário do Hemocentro Sede, o Posto de Coleta não possuía, no período de estudo, coleta de Hemocomponentes por aférese. 


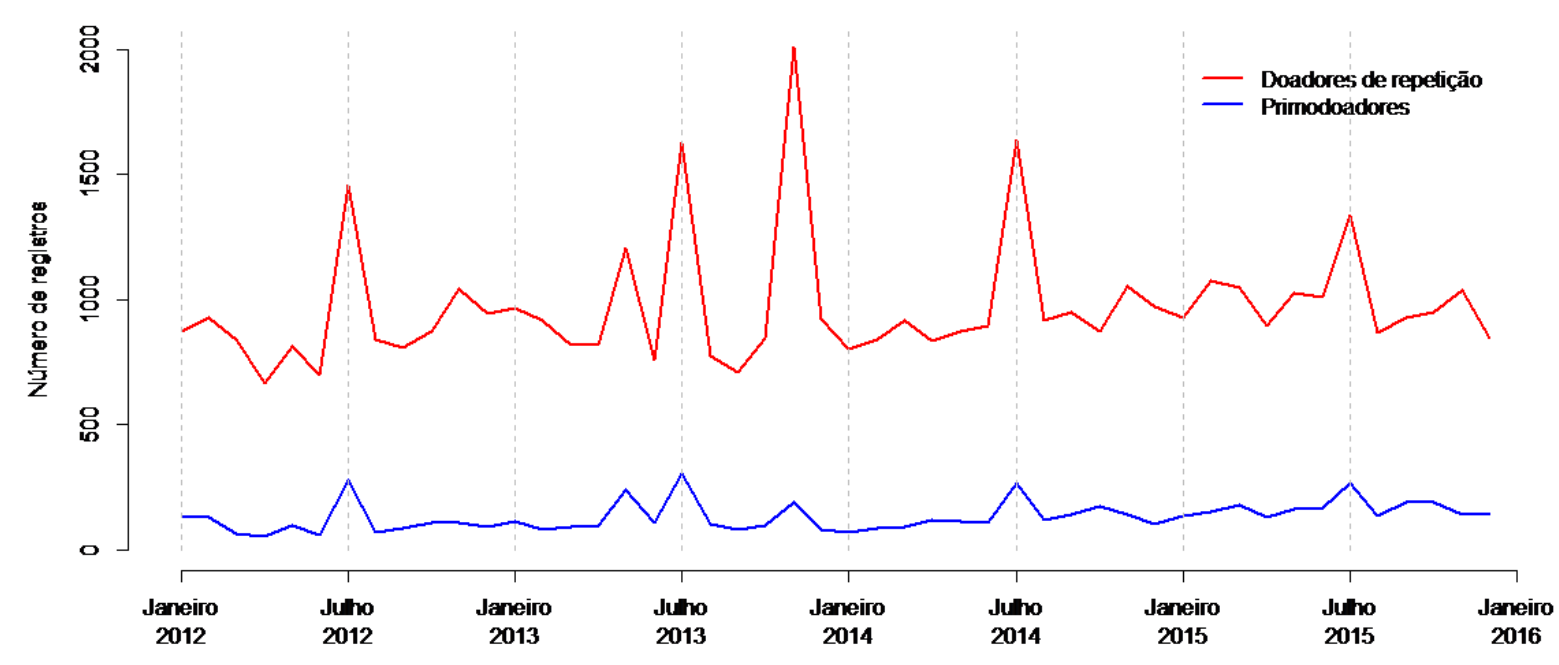

Figura 9. Número mensal de registros de doadores de repetição e primodoadores, Hemocentro (Posto de Coleta), janeiro de 2012 a dezembro de 2015.

Em novembro de 2013 foi encontrada a maior taxa de candidatos e doadores para essa unidade, com 2.653 candidatos e 2.202 doadores. Diferentemente do Hemocentro Sede, no Posto de Coleta, a campanha que mais captou doadores de sangue foi aquela referente ao Dia do Doador, campanha que ocorre em Novembro. Entretanto, para os doadores de primeira vez essa campanha não obteve o mesmo resultado quando comparada com os resultados apresentados para os doadores de repetição. A Figura 10 demonstra o fato. Para os doadores de primeira vez, a época de maior estímulo à doação de sangue é em Julho, no qual ocorre a campanha do Corpo de Bombeiros.

No Posto de Coleta, a maioria dos candidatos também foi do sexo masculino, com 59 $\%$ do total de candidatos $(\mathrm{n}=37.778)$. As candidatas à doação de sangue representaram $41 \%$ do total dos candidatos $(\mathrm{n}=25.763)$. As faixas etárias desses candidatos à doação estão apresentadas na Tabela 5. 


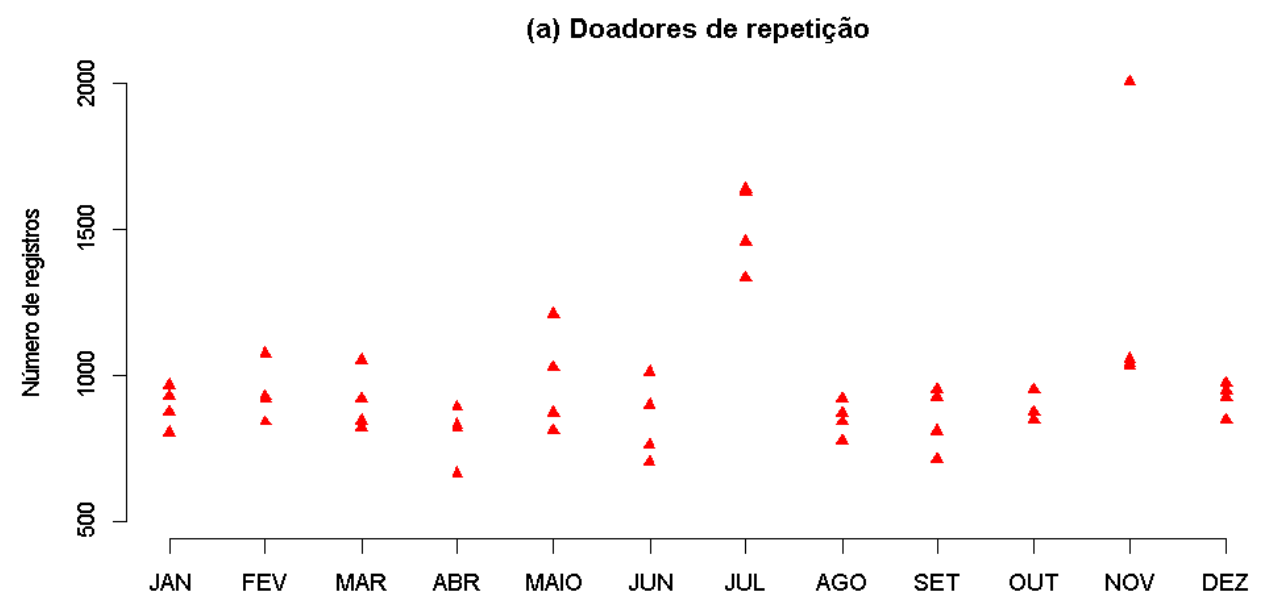

(b) Primodoadores

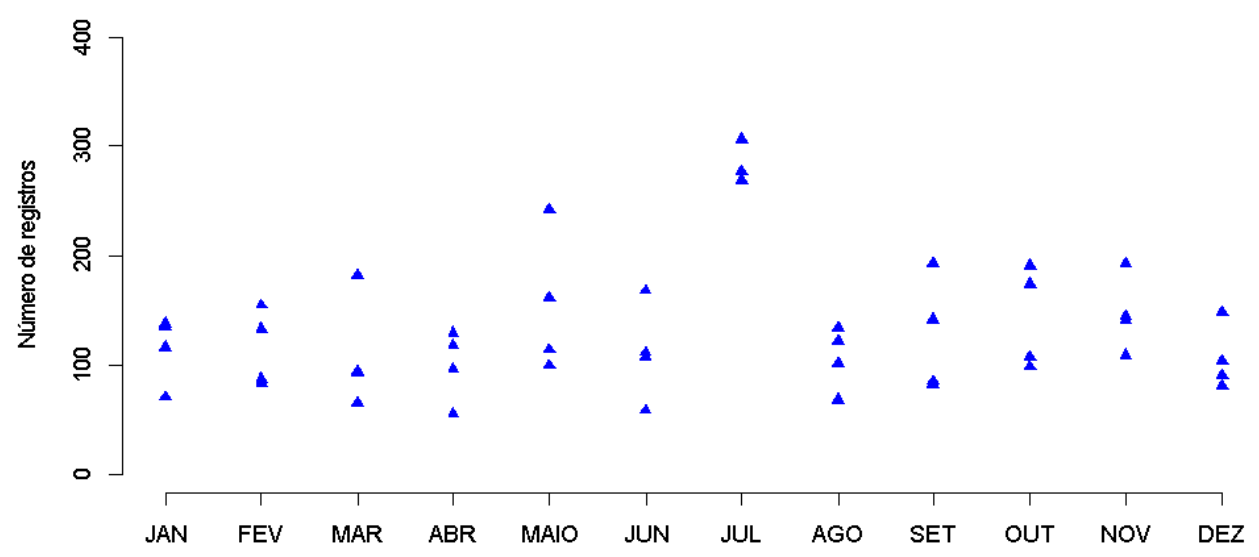

Figura 10. Número de registros de doadores de repetição e primodoadores a cada mês, Hemocentro (Posto de Coleta), Janeiro de 2012 a Dezembro de 2015. 
Tabela 5. Faixa etária dos candidatos à doação de sangue, Posto de Coleta.

\begin{tabular}{ccc}
\hline Masculino & Faixa Etária & Feminino \\
\hline $0,43 \%$ & 65 a 69 anos & $0,23 \%$ \\
$1,51 \%$ & 60 a 64 anos & $0,76 \%$ \\
$2,87 \%$ & 55 a 59 anos & $1,85 \%$ \\
$4,87 \%$ & 50 a 54 anos & $2,77 \%$ \\
$6,11 \%$ & 45 a 49 anos & $3,49 \%$ \\
$7,29 \%$ & 40 a 44 anos & $3,81 \%$ \\
$8,53 \%$ & 35 a 39 anos & $4,81 \%$ \\
$9,93 \%$ & 30 a 34 anos & $6,51 \%$ \\
$9,01 \%$ & 25 a 29 anos & $7,18 \%$ \\
$6,43 \%$ & 20 a 24 anos & $6,60 \%$ \\
$2,48 \%$ & 16 a 19 anos & $2,53 \%$ \\
\hline
\end{tabular}

Observou-se ainda que mais de $75 \%$ dos candidatos à doação de sangue estão classificados nas faixas etárias de 20 a 49 anos. O mesmo resultado foi encontrado para o Hemocentro Sede. Com relação à cor/raça, a distribuição dos candidatos à doação é apresentada na Tabela 6. A maior parte dos doadores foi representada pela cor/raça branca, com 71,16\% do total de candidatos $(\mathrm{n}=45.213)$.

Tabela 6. Distribuição por cor/raça dos candidatos à doação de sangue, Hemocentro Sede.

\begin{tabular}{ccc}
\hline \multicolumn{3}{c}{ Cor/Raça } \\
\hline Amarela & 624 & $0,98 \%$ \\
Branca & 45213 & $71,16 \%$ \\
Indígena & 0 & $0,00 \%$ \\
Morena & 12867 & $20,25 \%$ \\
Negra & 4389 & $6,91 \%$ \\
Parda & 437 & $0,69 \%$ \\
Sem cor registrada & 11 & $0,02 \%$ \\
\hline
\end{tabular}

\subsubsection{Séries Temporais}

A Tabela 7 mostra os valores- $p$ para o teste de Dickey e Fuller de estacionareidade, considerando as séries temporais originais e diferenciadas. Valores- $p$ menores que o nível de significância de 0,05 levam à decisão de se considerar a respectiva série homogênea. Assim, 
considerando os dados do Hemocentro Sede, os resultados da Tabela 3 sugerem que as séries para os números mensais de candidatos à doação, doadores, doadores de repetição e doadores novos (de primeira vez) podem ser consideradas estacionárias após diferenciadas. Como exceção, a série temporal para doações por aféreses não necessita ser diferenciada para ser considerada estacionária.

Tabela 7. Valores-p para o teste de Dickey e Fuller de estacionareidade, considerando as séries temporais originais e diferenciadas. Dados do Hemocentro (sede) e Posto de Coleta, Janeiro de 2012 a Dezembro de 2015.

\begin{tabular}{lccccc}
\hline & \multicolumn{2}{c}{ Hemocentro (sede) } & & \multicolumn{2}{c}{ Posto de Coleta } \\
\cline { 2 - 3 } \cline { 5 - 6 } Série & $\begin{array}{c}\text { Série } \\
\text { original }\end{array}$ & $\begin{array}{c}\text { Série } \\
\text { diferenciada }\end{array}$ & & $\begin{array}{c}\text { Série } \\
\text { original }\end{array}$ & $\begin{array}{c}\text { Série } \\
\text { diferenciada }\end{array}$ \\
\hline Candidatos à doação & 0,24 & $<0,01$ & & 0,02 & $<0,01$ \\
Doadores & 0,22 & $<0,01$ & & 0,02 & $<0,01$ \\
Doadores de repetição & 0,05 & $<0,01$ & & 0,05 & $<0,01$ \\
Primodoadores & 0,38 & $<0,01$ & & 0,08 & $<0,01$ \\
Aféreses & 0,01 & $<0,01$ & & - & - \\
\hline
\end{tabular}

A Figura 11 mostra os gráficos de autocorrelação (ACF) para as séries temporais relativas ao número mensal de candidatos à doação, doadores, doadores de repetição, primodoadores e doações por aféreses, considerando os dados do Hemocentro Sede. As linhas horizontais pontilhadas exibidas nos gráficos referem-se a intervalos utilizados para se testar a hipótese de que a ACF é igual a zero (ausência correlação com os k meses anteriores) para um dado deslocamento de tamanho ${ }^{k}$ meses. Os gráficos na Figura 11 mostram que em um dado mês é inversamente associado aos que se observa no mês anterior. Nota-se que existe um comportamento cíclico de 12 meses. 

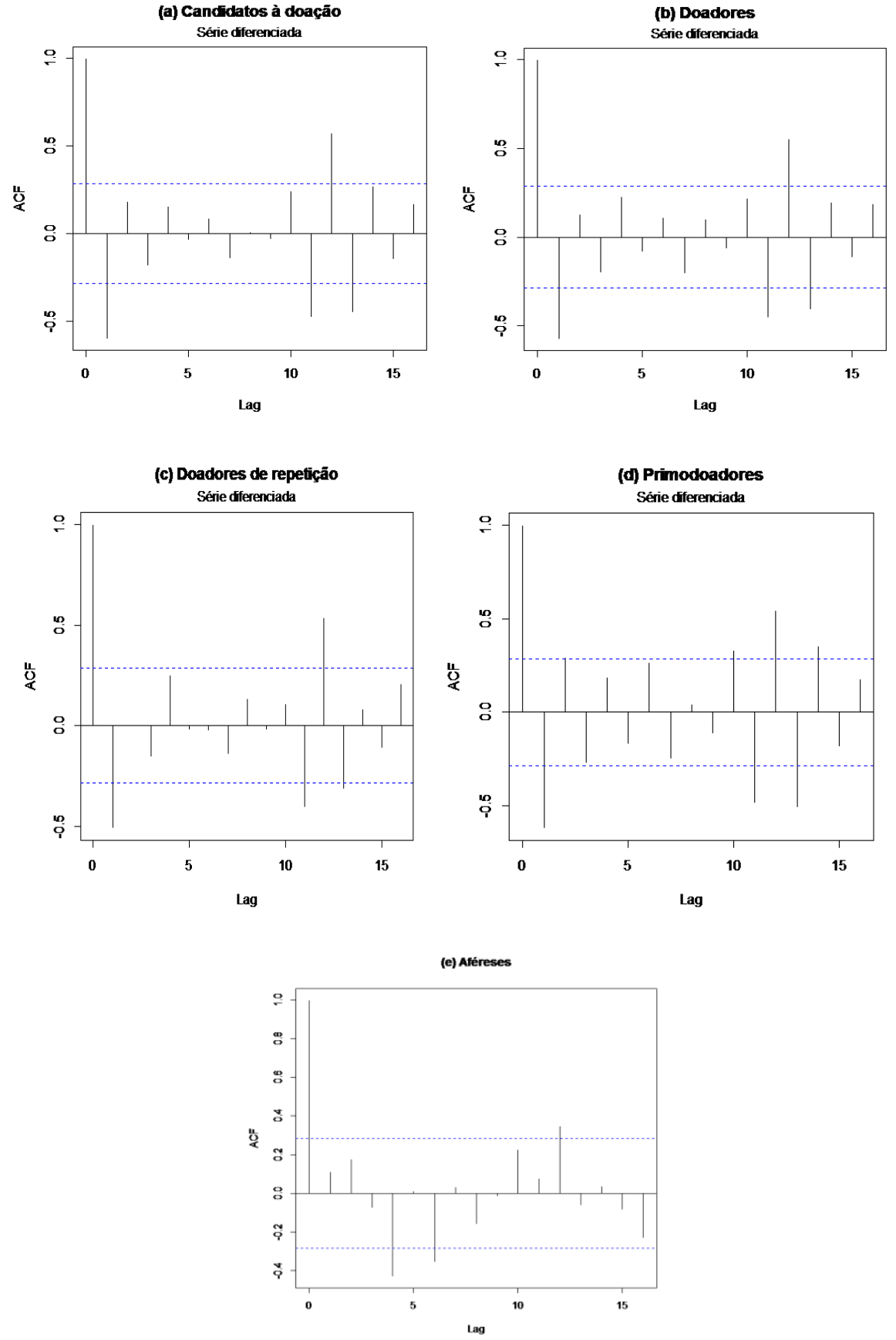

Figura 11. Funções de autocorrelação (ACF) para o número mensal de candidatos à doação (a), doadores (b), doadores de repetição (c), primodoadores (d) e doações por aféreses, Hemocentro Sede, Janeiro de 2012 a Dezembro de 2015.

A Figura 12, mostra os gráficos de autocorrelação (ACF) para as séries temporais relativas ao número mensal de candidatos à doação, doadores, doadores de repetição e primodoadores, para os dados do Posto de Coleta. 

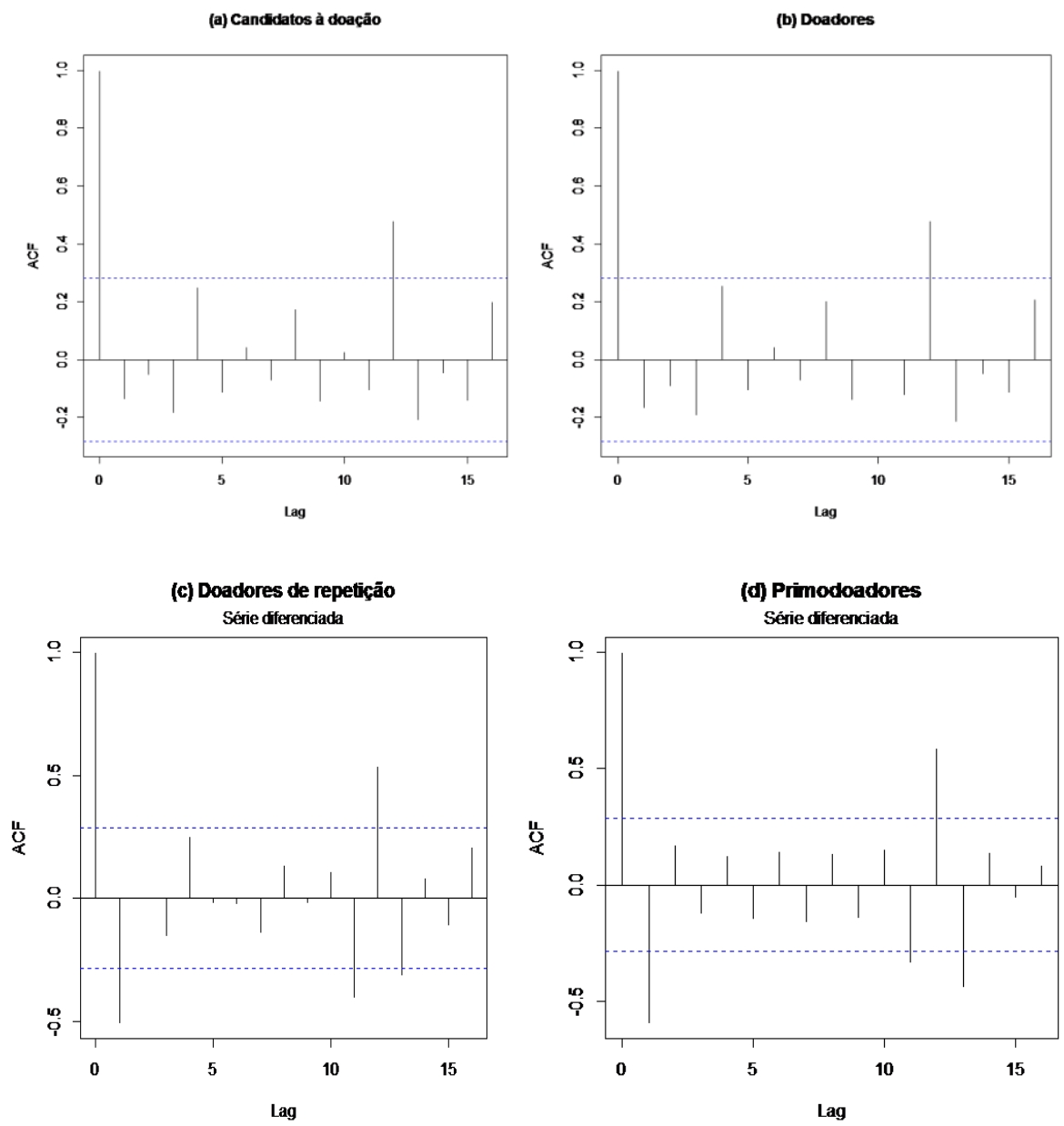

Figura 12. Funções de autocorrelação (ACF) para o número mensal de candidatos à doação (a), doadores (b), doadores de repetição (c), primodoadores (d) e doações por aféreses, Hemocentro (Posto de Coleta), Janeiro de 2012 a Dezembro de 2015.

A Figura 13, no painel superior, apresenta um gráfico da função de correlação cruzada $(\mathrm{CCF})$ entre os números de mala direta enviada e o número de doadores de repetição para o Hemocentro Sede, sendo estas séries diferenciadas. Observando o gráfico, pode-se perceber que após 6 meses do envio da mala direta o número de doadores está fortemente correlacionado ao número de mala direta enviada. Nota-se que a série diferenciada T6 apresenta de maneira bastante evidente a forte correlação existente entre essas duas séries. Apesar de 6 meses parecer um tempo longo para a resposta dos doadores, após receber a mala direta deve-se considerar que o momento zero (T0) é aquele em que se registra o envio da mala direta no sistema interno do Hemocentro. Sendo assim, se considerar todas as etapas que a mala direita percorre, o tempo de 6 meses é adequado. Entretanto apesar de haver uma forte correlação, o envio de mala direta 
não se mostra uma ferramenta eficaz, visto que após um certo número de malas diretas enviadas o número de doadores não aumenta. Dizer que há correlação não significa dizer que existe resposta dos doadores ao estímulo mala direta. O mesmo não foi observado no Posto de Coleta, local em que não houve correlação entre as malas diretas enviadas e o número de doadores, conforme apresentado na figura 14.
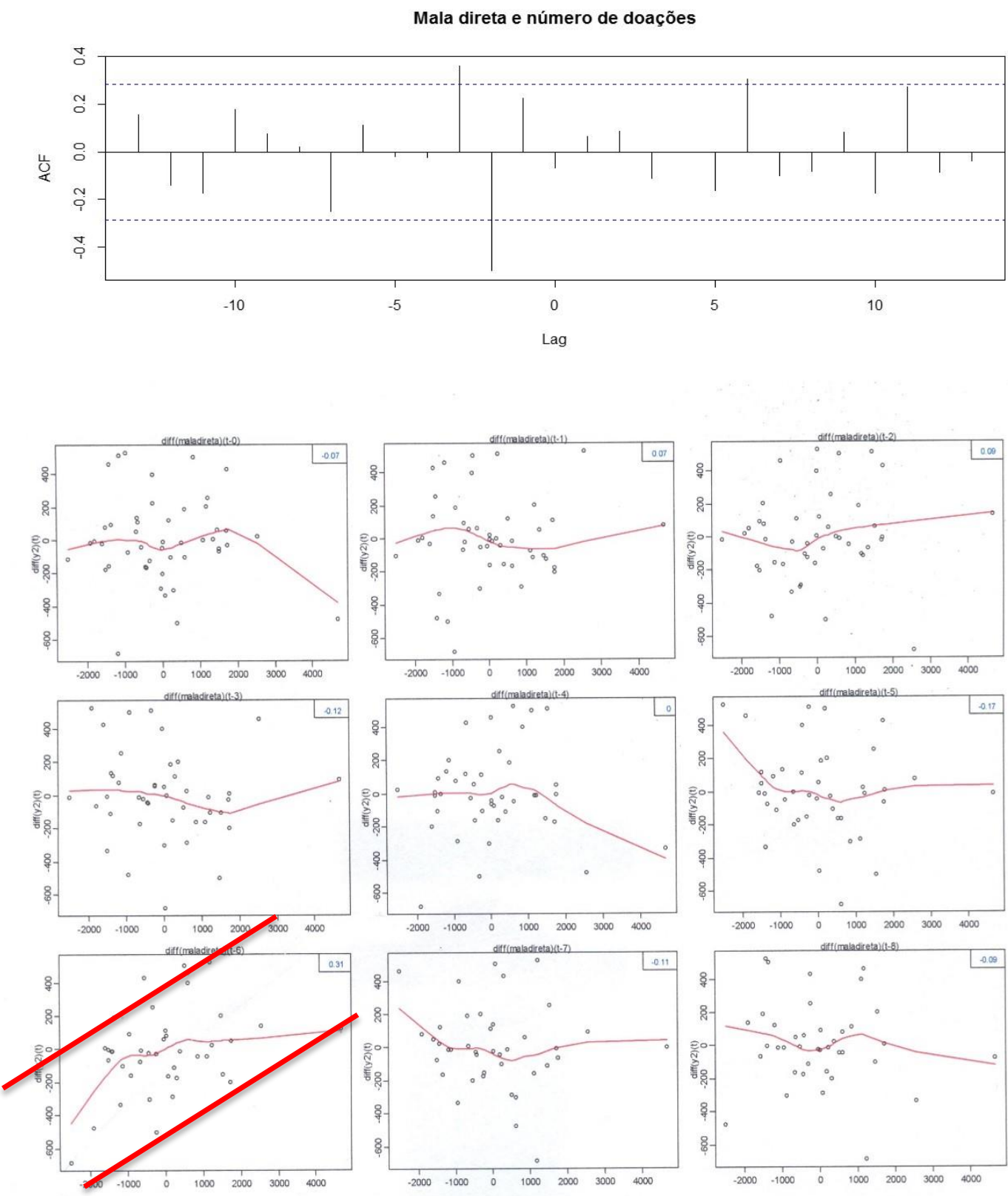

Figura 13. Funções de correlação entre o número de mala direta enviada e o número de doadores de repetição, Janeiro de 2012 a Dezembro de 2015, no Hemocentro Sede. 
Logo abaixo do gráfico da CCF (Figura 13), são exibidos gráficos de dispersão ilustrando a correlação entre o número de malas diretas enviadas em um dado mês e o número de doadores $\mathrm{k}$ meses após, com $\mathrm{K}$ variando de 0 a 8 . No gráfico relativo a $\mathrm{K}=6$ ( o primeiro gráfico da última linha da Figura 13 apresenta a correlação existente entre o número de cartas enviadas e o retorno de doadores após 6 meses.
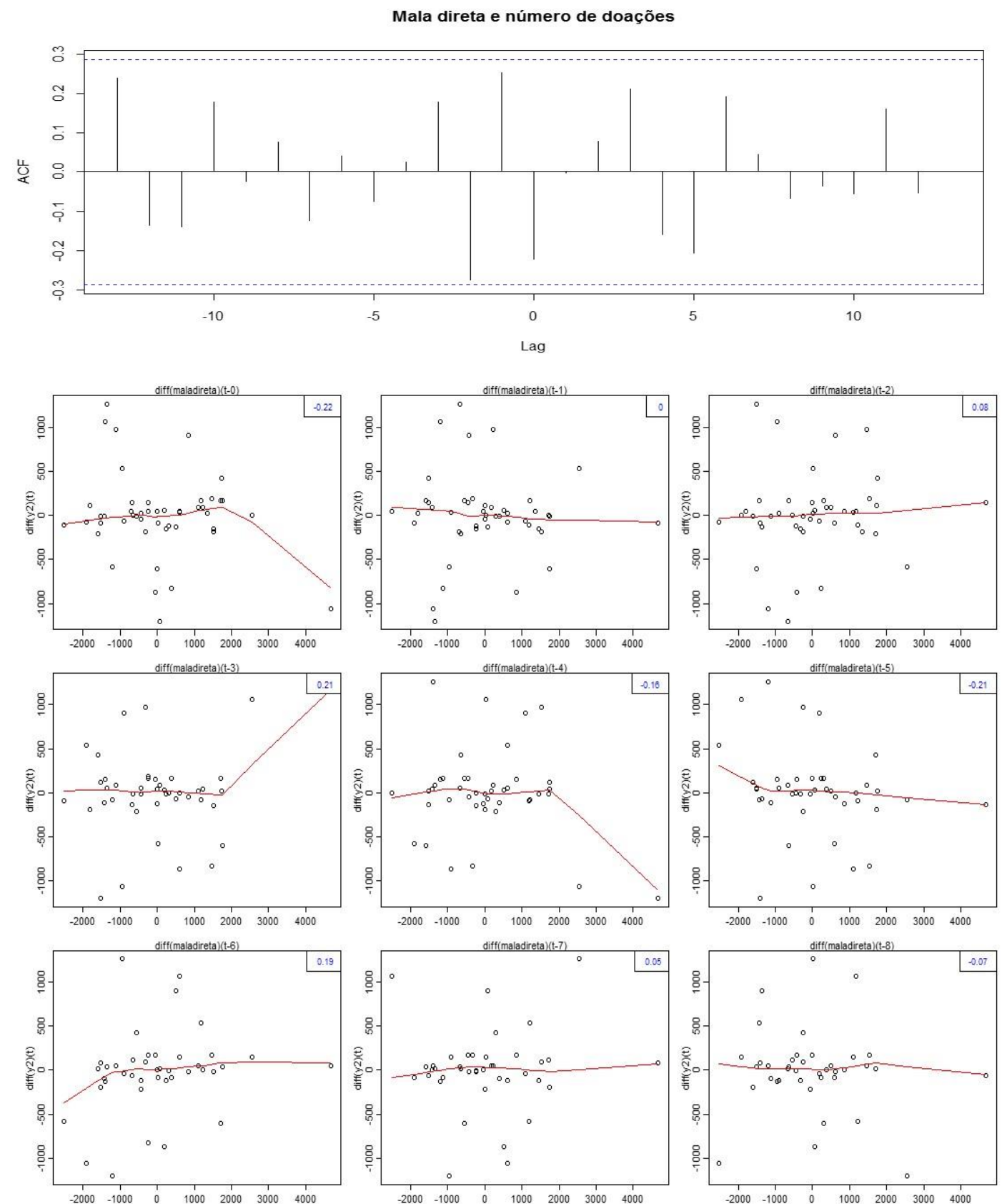

Figura 14 Funções de correlação entre o número de mala direta enviada e o número de doadores de repetição, Janeiro de 2012 a Dezembro de 2015, no Posto de Coleta. 
Outras funções de correlação cruzadas foram realizadas. Entretanto, não foi observada nenhuma correlação significativa entre elas. Todas as estratégias de captação foram testadas, porém sem apresentar resultados significativos em relação à ACF. Esse resultado não significa que as ferramentas não apresentaram retorno, significa que as observações de uma série não se correlacionam com as observações de outra série. As ferramentas de captação testadas foram Campanhas; Mala direta - Doador; Telefonema - Doador; Mala direta - Paciente; Abordagens em Fila de Visita; Telefonema - Transfundidos; E-mails; Faixas - Outdoor; Mobilizado (Mídia); e Torpedos - SMS.

\subsection{Análise prospectiva}

A análise prospectiva dos dados foi realizada no período de Novembro/2017 e Dezembro/2017. O questionário apresentado no Anexo I e o TCLE (Anexo II) foram entregues aos doadores que concordaram em participar da pesquisa. No Hemocentro Sede foi distribuído um total de 122 questionários, sendo que 10 (8,2\%) foram considerados inválidos e 2 (1,6\%) estavam em branco. Os resultados estão apresentados na Figura 15.

\section{Preferência do entrevistados com relação as ferramentas de captação}

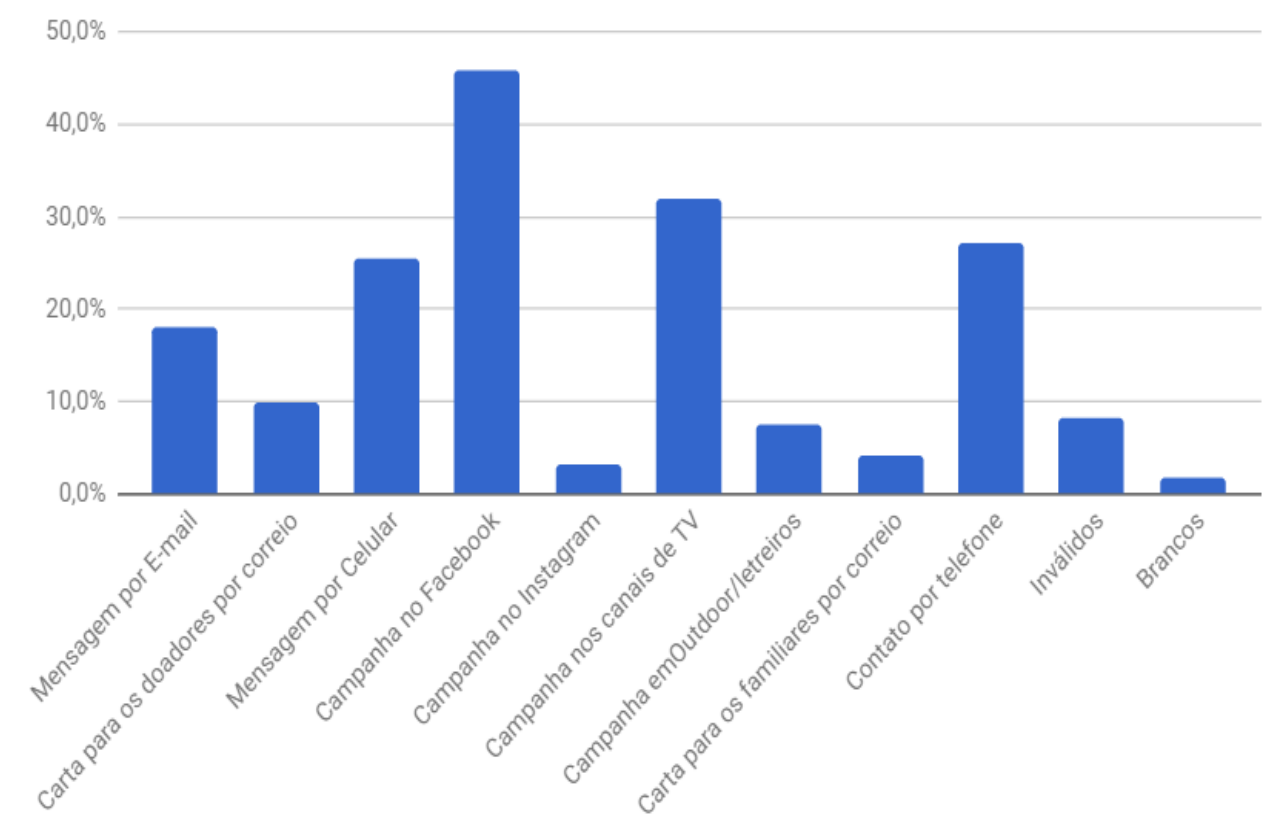

Figura 15. Preferência dos entrevistados com relação às ferramentas de captação, Hemocentro Sede. 
Baseado nesse gráfico, é possível observar que $45 \%$ dos doadores preferem o contato via Facebook Inc.. Com relação às mídias sociais utilizadas pelos doadores observaram-se que o Facebook e WhatsApp são as mídias mais utilizadas.

Na Figura 16, é possível observar os dados relativos aos questionários. A grande utilização do Facebook é um dos fatos que ajudam a explicar a efetividade das campanhas realizadas pelo Facebook, como as campanhas do Corpo de Bombeiros e também do mês do doador.

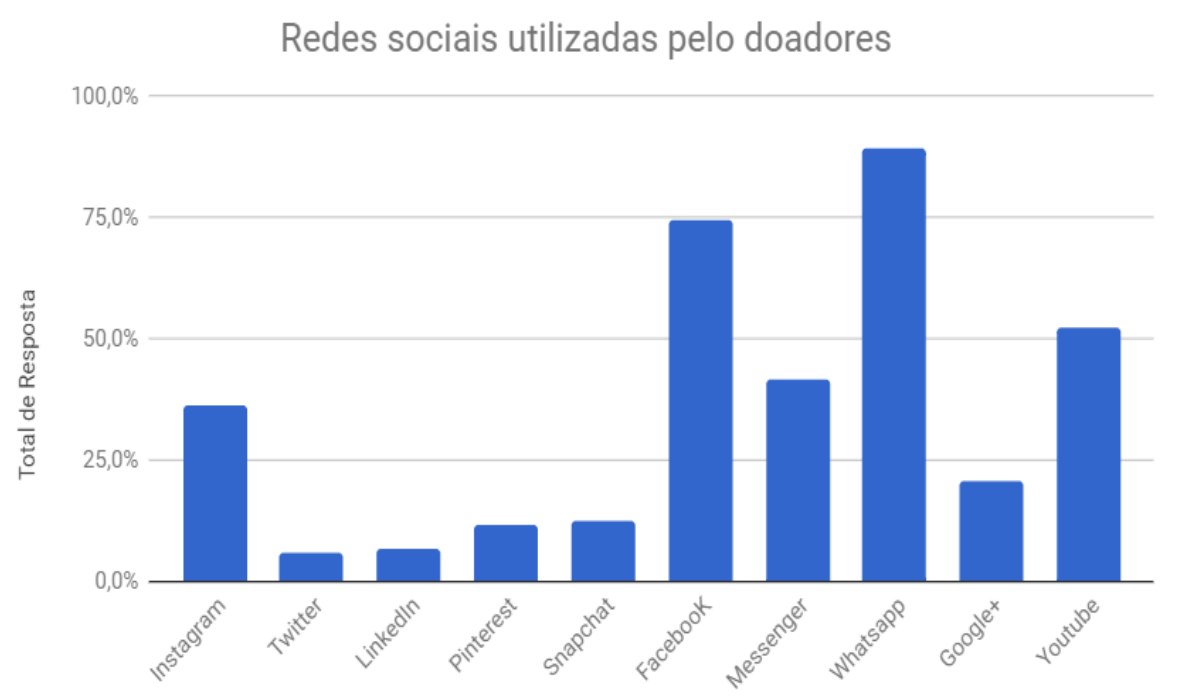

Figura 16. Mídias sociais utilizadas pelos entrevistados, Hemocentro Sede.

No Posto de Coleta foi verificado que houve grande número de questionários inválidos, pois muitos candidatos à doação assinalaram mais de duas ferramentas de captação (Figura 17), o que corresponde a aproximadamente $30 \%$ do total. 


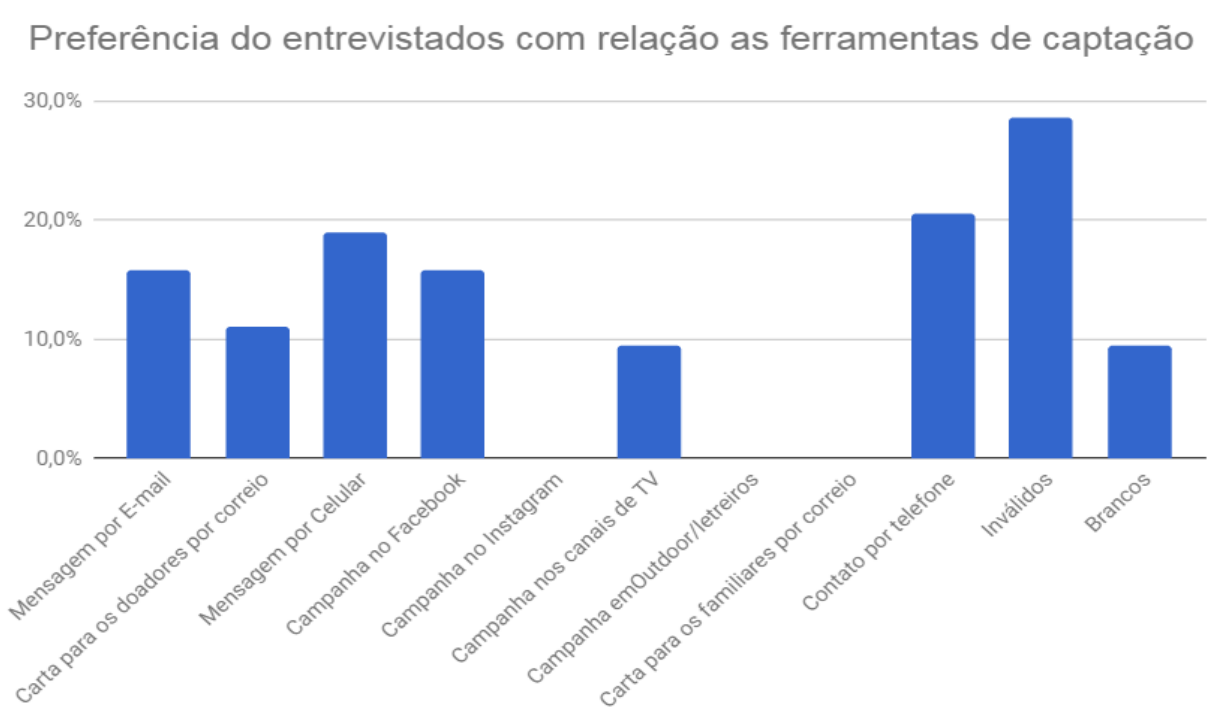

\section{Figura 17. Mídias sociais utilizadas pelos entrevistados, Posto de Coleta.}

Apesar de haver grande número de questionários inválidos houve surpresa ao analisar esses questionários pois houveram respostas escritas pelos doadores dizendo que não precisam de ferramentas de captação para doar, pois os mesmos já estavam conscientes da importância de doar sangue. Esses fatos não foram observados no Hemocentro Sede, novamente ficando evidente que existe diferença entre o público que frequenta esses locais.

No Posto de Coleta, o uso das mídias sociais também foi similar ao Hemocentro Sede, sendo que o Facebook e o WhatsApp foram as mídias sociais mais utilizadas pelos candidatos à doação de sangue. A Figura 18 representa os dados obtidos no Posto de Coleta.

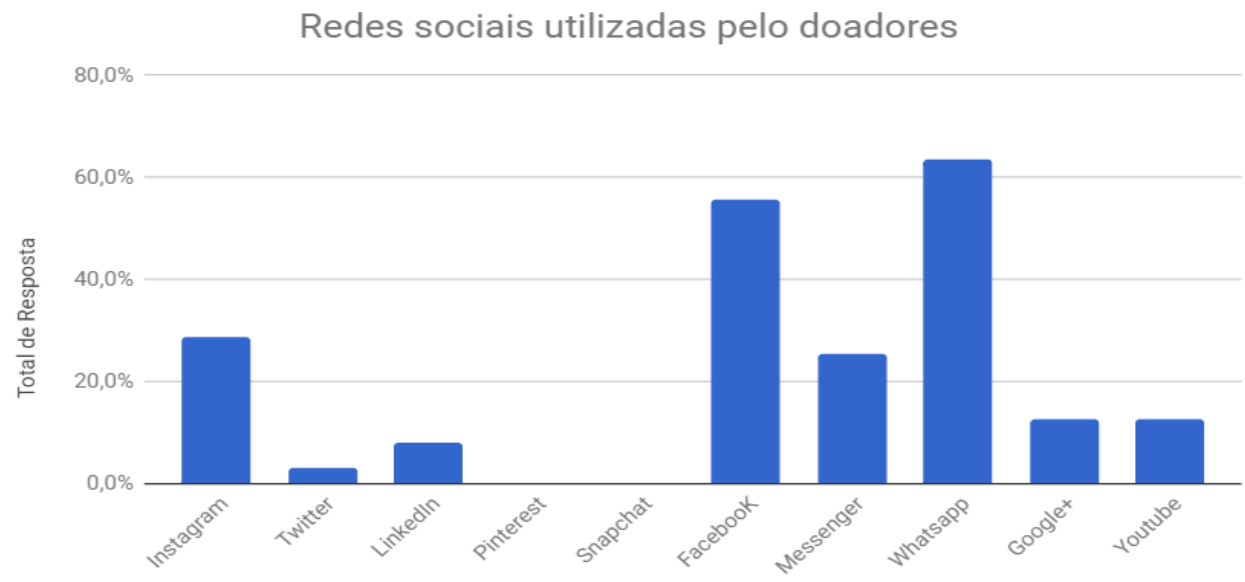

Figura 18. Preferência do entrevistados com relação às ferramentas de captação, Posto de Coleta. 


\subsection{Análise Custo-Efetividade}

Com a análise do custo-efetividade das ferramentas de captação foi possível definir que as malas diretas possuem uma das menores taxas de retorno de doador. Ficou evidente que as populações que frequentam a Sede e o Posto de Coleta são distintas. A Mala Direta-Pacientes que possui impacto na vinda dos doadores no Hemocentro Sede, não possui tal impacto para o estímulo dos doadores à comparecerem no Posto de Coleta. O Hemocentro Sede é muito próximo ao Hospital das Clinicas de Ribeirão Preto, hospital que atende pacientes de diversas cidades da região. Esses pacientes muitas vezes são transportados de ônibus, passando o dia no Hospital havendo tempo significativo para que os acompanhantes desses pacientes realizem doações no Hemocentro Sede. A maioria dos pacientes que ficam internados no Hemocentro Sede recebem a mala direta para pacientes, explicando o fato de que essa ferramenta possua impacto maior na Sede que no Posto de Coleta. O Posto de Coleta está na região central, ficando próximo ao Hospital de Emergência do Hospital das Clínicas, hospital que por sua vez recebe urgências, sendo os tratamentos prolongados realizados na outra unidade, fato este que parcipa no pequeno impacto que as malas diretas para pacientes apresentam para o estimulo dos doadores que doam no posto de Coleta.

A Figura 19 e a Figura 20 representam as taxas de retorno dos candidatos à doação apto e inapto. Foi considerado auto-motivação quando o doador não atribuiu nenhuma ferramenta de captação como estímulo para doação.

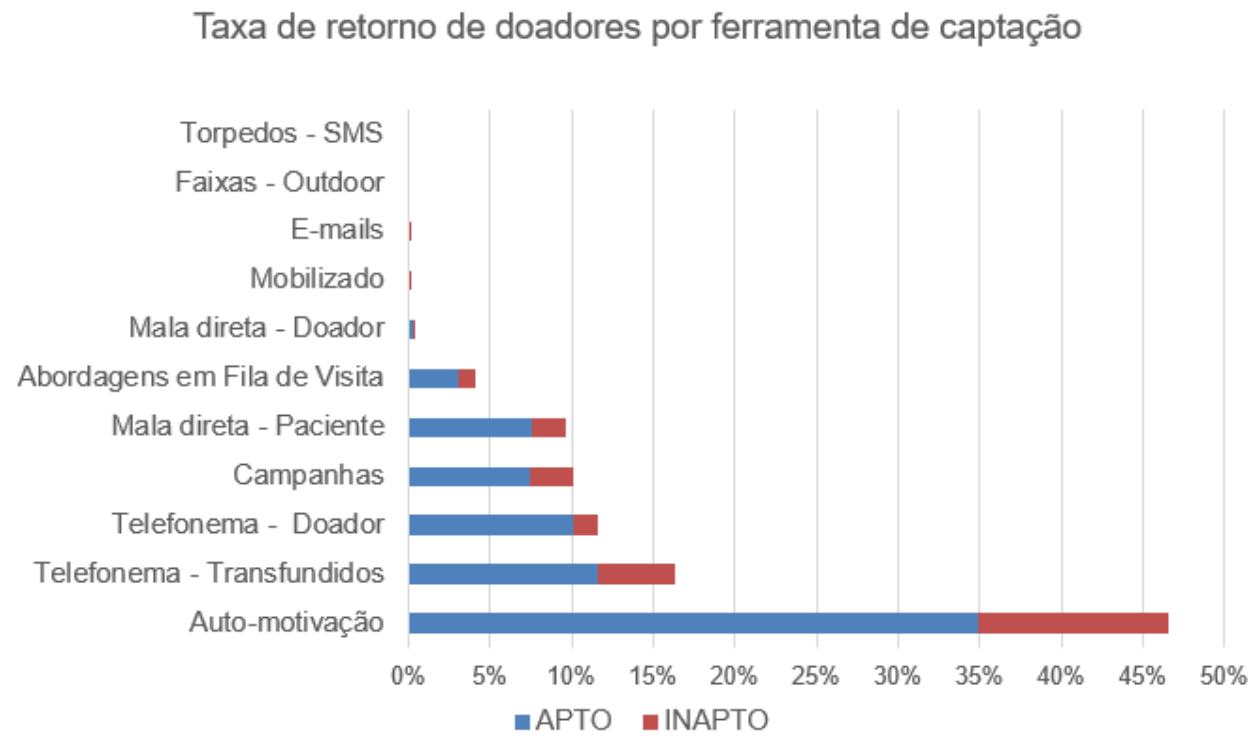

Figura 19. Taxa de retorno, por ferramentas de captação, no Hemocentro Sede. 


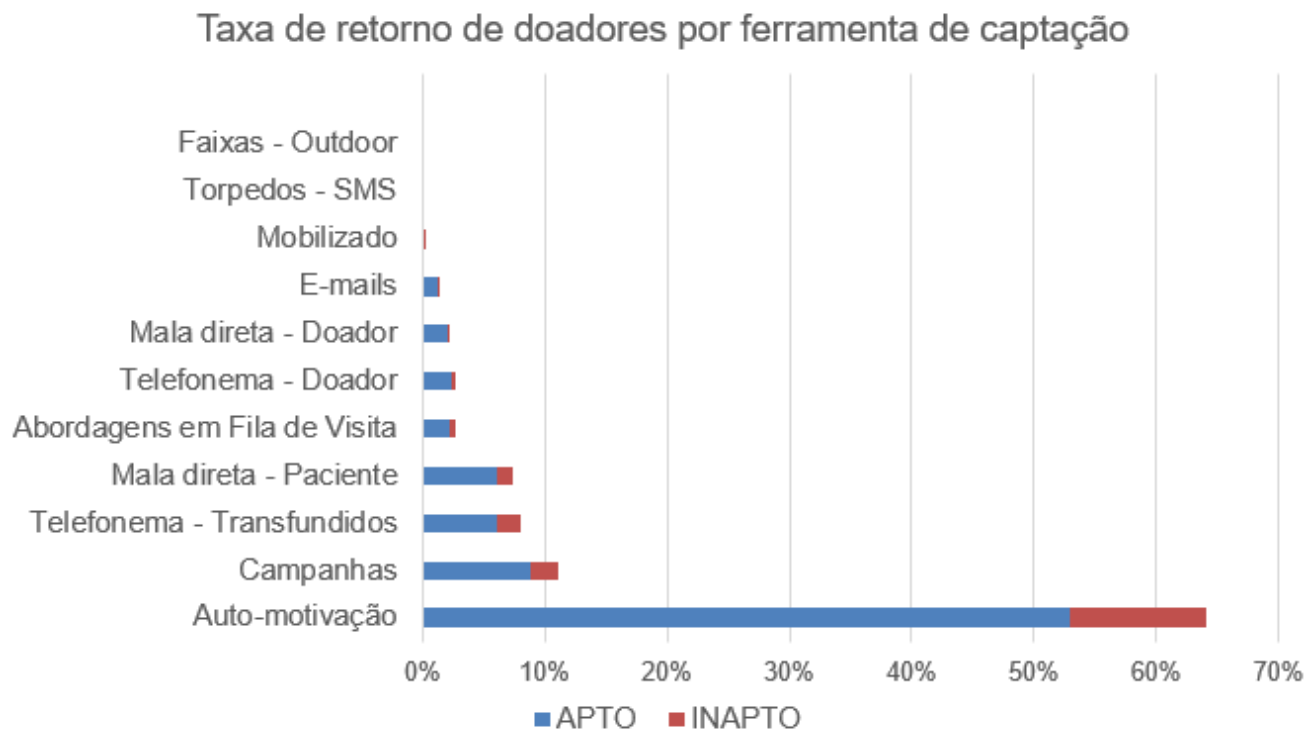

\section{Figura 20. Taxa de retorno, por ferramentas de captação, no Posto de Coleta.}

Analisando as figuras 21 e 22 verificou-se que as ferramentas de captação de doadores que apresentam as melhores taxas de retorno são aquelas que trabalham com os dores de reposição, ou seja, aqueles candidatos que possuem algum motivo, conhecem alguém que recebeu transfusão, e estão repondo o sangue utilizado. Esses doadores de reposição não doam com frequência e possuem motivo específico para doar sangue, diferentemente dos doadores de repetição, conscientes da importância de doarem sangue para a manutenção dos estoques dos hemocentros. $\mathrm{O}$ contato telefônico com os doadores de repetição também apresentou bom retorno de doadores a um custo baixo, sendo a primeira colocada dentre as ferramentas de captação que trabalham com doação espontânea.

O custo-efetividade das ferramentas de captação foi analisado que a ferramenta com melhor desempenho foi o telefone para transfundidos, seguido das abordagens em fila de visita. Essas duas ferramentas foram as ferramentas que mais estimularam os doadores comparecer ao Hemocentro Sede ou Posto de Coleta com um dos custos mais baixos. Entretanto essas duas ferramentas trabalham a doação de reposição. As Figuras 23 e 24 demonstram os resultados para cada uma das ferramentas. 


\section{Custo-Efetividade das ferramentas de \\ captação - Sede}

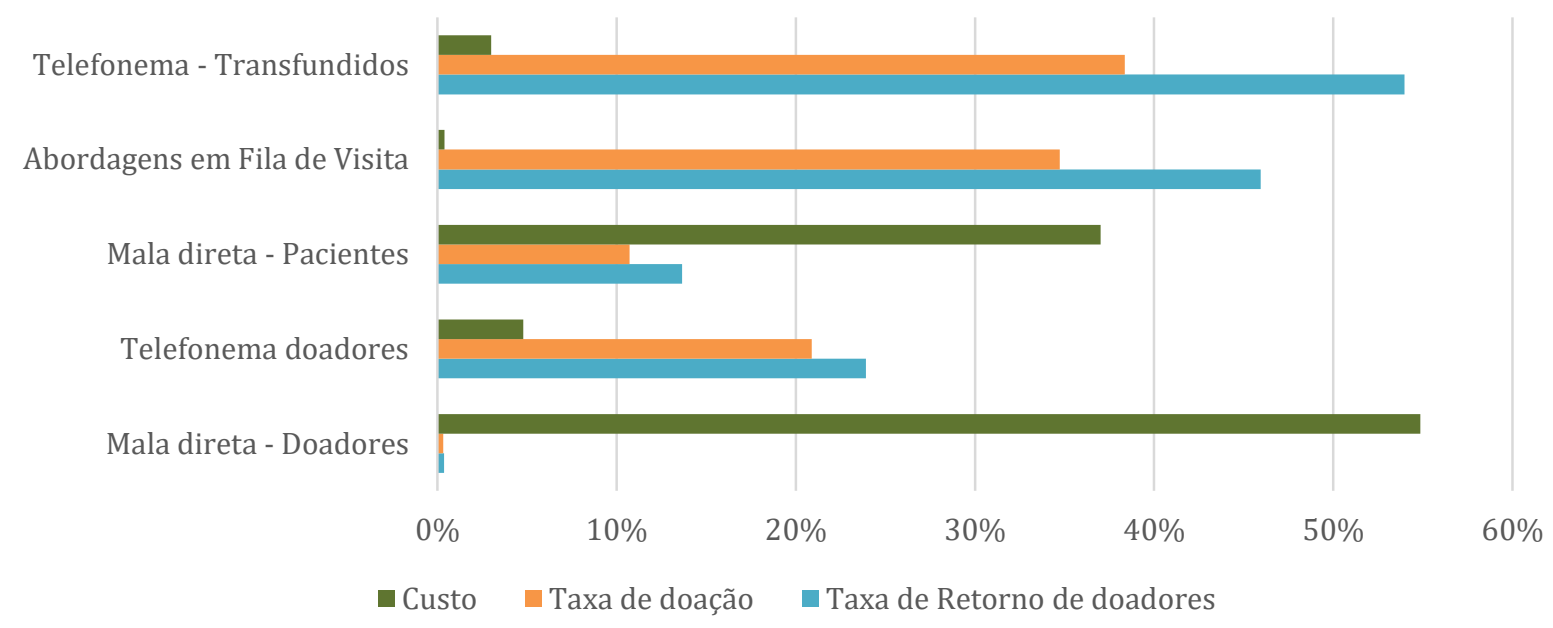

Figura 21. Custo-efetividade, por ferramentas de captação, no Hemocentro Sede.

\section{Custo-Efetividade das ferramentas de captação - Posto de Coleta}

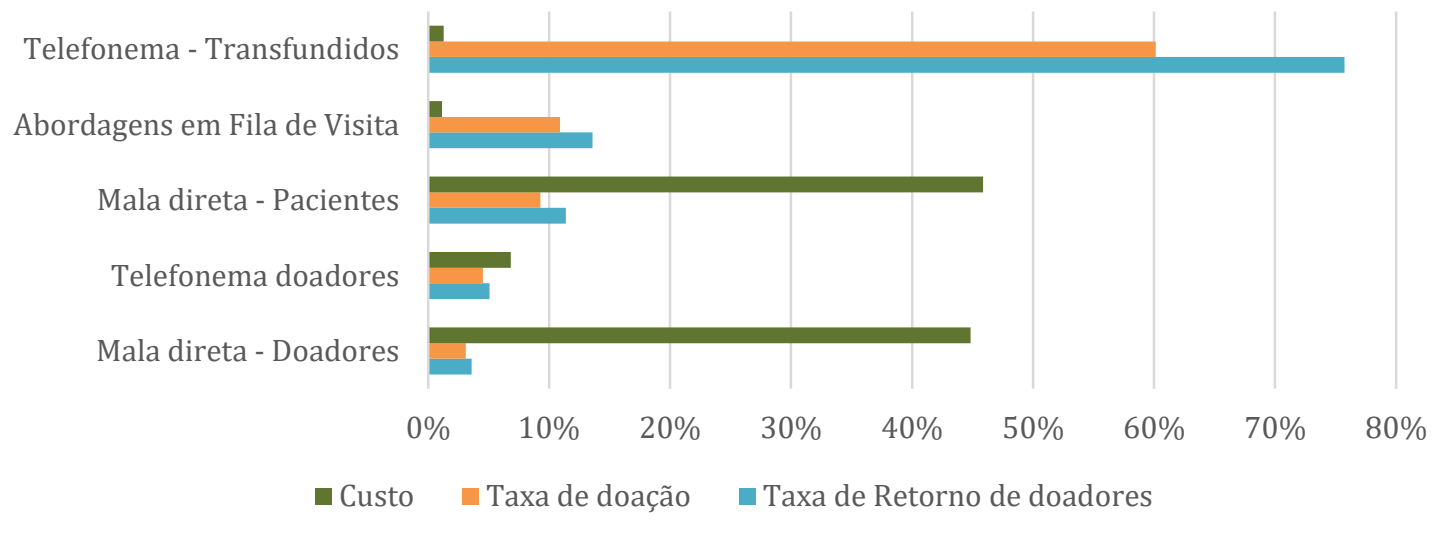

Figura 22. Custo-efetividade, por ferramentas de captação, no Posto de Coleta.

Em geral as ligações para os candidatos a doação de sangue, por ser uma ferramenta mais individualizada e personalizada apresentam um bom custo-efetividade. Entretanto as malas diretas para os doadores ou pacientes apresentam custo elevado e o retorno de doadores é muito pouco em relação ao custo. Somadas as malas diretas para pacientes e doadores representam aproximadamente $90 \%$ dos custos de captação e trazem retorno de candidatos abaixo dos $10 \%$ do total, tanto em candidatos (taxa de retorno de doadores) com em doações 
(taxa de doação). De acordo com GEMELLI et. al. (2018) o uso de SMS contribui para aumento dos doadores de repetição, neste estudo o SMS pode não ter apresentado impacto semelhante pois somente uma operadora de telefonia enviava mensagem de SMS para os doadores, além disso o uso de SMS foi descontinuado durante esse estudo. 


\section{Considerações finais}

De acordo com os nossos dados, observou-se que as malas diretas enviadas apresentam correlação entre o número de cartas enviadas e o número de doadores 6 meses após o envio. Porém não são eficazes para o retorno e estímulo para as pessoas realizarem a doação de sangue. A malas diretas são as ferramentas que apresentam o maior custo para um retorno pouco significativo. A ferramenta que apresenta melhor custo-efetividade envolve doadores de reposição, essas ferramentas são o telefonema para os transfundidos e as abordagens em fila de visita. O contato telefônico por ser um atendimento mais personalizado apresenta boas expectativas de retorno dos doadores e também envolvem os doadores espontâneos. Observouse também que não é possível escolher um único tipo de ferramenta de captação, é necessário identificar aquelas com melhor custo-efetividade, avaliando o estoque de modo a otimizar o uso das ferramentas de captação. Esse trabalho contribui para elaboração de um instrumento para análise das ferramentas de captação que apresentam maior custo-efetividade no contexto da cidade de Ribeirão Preto, podendo ser um modelo para estudos semelhantes desenvolvidos em outros hemocentros, a fim de otimizar a captação dos doadores de sangue.

Após esse estudo detalhado recomendamos que os serviços de Hemoterapia façam um estudo detalhado das taxas de retorno de doadores que suas ferramentas de captação apresentam, utilizando com ponto de partida a metodologia aqui demonstrada. Substituir as ferramentas que não propiciam contato mais individualizadas e que não são imediatas, ou seja demoram para chegar no destinatário, por ferramentas mais individualistas é uma ação adequada, assim como iniciar ou manter rotinas de telefones para os doadores ou familiares de pacientes, o estudo de GEMELLI et. al. (2018) corroboram com a implementação de ferramentas com atendimento mais personalizado, como contato telefônico e mensagens de celulares, como por exemplo SMS.

Outro ponto forte desse trabalho foi demostrar que as campanhas nas mídias sócias apresentam um bom retorno e quando bem elaboradas atingem um grande público, ferramentas estas que possuem custo zero, como Facebook, Instagram, Google + e YouTube.

Por fim vale ressaltar que é fundamental transformar aqueles doadores de reposição em doadores de repetição, realizando as doações de maneira espontânea, para isso um atendimento feito por profissionais bens treinados e educados, excedendo a expectativa do cliente fará aumentar as taxas de fidelização dos clientes, nossos doadores. 


\section{Referências Bibliográficas}

ABHH, ASSOSCIAÇÃO BRASILEIRA DE HEMATOLOGIA, HEMOTERAPIA E TERAPIA CELULAR. O que é o Programa? 2012. Disponível em: < http://www.abhh.org.br/joomla/pt-br/associacao/acreditacao/o-que-e-o-programa>. Acesso em: 07/12/2015.

ABNT NBR ISO 9001:2015, Sistema de Gestão da Qualidade - Requisitos.

BRASIL. Constituição (1988). Constituição da República Federativa do Brasil. Brasília, DF: Senado Federal: Centro Gráfico, 1988. 292 p.

Brasil. Ministério da Saúde. Secretaria de Atenção à Saúde. Departamento de Atenção Especializada e Temática. Manual de orientações para promoção da doação voluntária de sangue/Ministério da Saúde, Secretaria de Atenção à Saúde. Departamento de Atenção Especializada e Temática. Brasília. 2015. 152 p.

BRASIL. Ministério da Saúde. Gabinete do Ministro. Portaria de Consolidação $\mathrm{N}^{\circ} .05$, de 03 de outubro de 2017. Consolidação das normas sobre as ações e os serviços de saúde do Sistema Único de Saúde. Diário Oficial da União, Poder Executivo, Brasília, DF, 03 outubro 2017. Seção 1, Suplemento, p. 360.

Dickey, D. A., \& Fuller, W. A. (1979). Distribution of the estimators for autoregressive time series with a unit root. Journal of the American statistical association, 74(366a), 427-431.

FROTA, M. Z. M.; A Importância da Interlocução no Processo de Captação de Doadores na Fundação Hemoam.2005. 26f. Tese (Especialista em Saúde). Centro De Informação Científica E Tecnológica, Fundação Oswaldo Cruz, Manaus. 2005.

FUNDAÇÃO NACIONAL DA QUALIDADE. Cadernos sobre: Satisfação do Cliente. Ebook, 2015. Disponível em: < http://www.fnq.org.br/informe-se/publicacoes/e-books >. Acesso em $07 / 12 / 2015$.

GEMELLI, C. N.; CARVER, A.; GARN, A.; WRIGHT, S. T.; DAVISON, T. E. Evaluation of the impacto of a personalized postdonation short messaging servisse on the retention of whole blood donors. Transfusion, v. 58, p. 701-709, 2018.

HEMOCENTRO DE RIBEIRÃO PRETO. Manual para Unidades Associadas 2016. Disponível em: < http://www.hemocentro.fmrp.usp.br/wp-content/uploads/pdf/man_ent.pdf>. Acesso em: 10/02/2017. 
HEMOCENTRO DE RIBEIRÃO PRETO. Relatório de Gestão 2015. Disponível em: 〈http://www.hemocentro.fmrp.usp.br/wp-content/uploads/2016/07/rel_ativ_2015.pdf>.

Acesso em: 10/02/2017.

LOURENÇON, A. F.; SANTOS ALMEIDA, R. G.; FERREIRA, O.; MARTINEZ, E. Z. Evaluation of the return rate of volunteer blood donors. Revista Brasileira de Hematologia e Hemoterapia (Impresso), v. 33, p. 190-194, 2011.

MARTINEZ, E. Z.; LOURENÇON, A. F.; ACHCAR, J. A.; ZOZOLOTTO, H.C.; FERREIRA, O. Uso de modelos Bayesianos de volatilidade estocástica no estudo temporal dos registros de doações de sangue. Cadernos Saúde Coletiva (UFRJ), v. 18, p. 597-603, 2010.

MINISTÉRIO DA SAÚDE. Secretaria de Gestão do Trabalho e da Educação na Saúde. Departamento de Gestão do Trabalho na Saúde. Técnico em hemoterapia. Brasília. 2013. 292 p.

MINISTÉRIO DA SAÚDE. Secretaria de Atenção à Saúde. Departamento de Atenção Especializada e Temática. Caderno de Informação Sangue e Hemoderivados - Dados 2014. 9. ed. - Brasília. 2015. 154 p.

SECRETÁRIA GERAL PARLAMENTO DO ESTASO DE SÃO PAULO. DECRETO N. 32.849, DE 23 DE JANEIRO DE 1991. Cria, no âmbito da Secretaria da Saúde, a HEMOREDE - Rede Estadual de Hematologia-Hemoterapia e dá outras providências. São Paulo 1991. Disponível em: <http://www.al.sp.gov.br/repositorio/legislacao/decreto/1991/decreto32849-23.01.1991.html>. Acesso em: 10/02/2017. 


\section{Bibliografias}

BRASIL. Ministério da Saúde. Agência Nacional de Vigilância Sanitária. Resolução - RDC $N^{\circ}$. 34, de 11 de junho de 2014. Dispõe sobre as Boas Práticas no Ciclo do Sangue. Diário Oficial da União, Poder Executivo, Brasília, DF, 16 jun. 2014. Seção 1, p. 50.

BRASIL. Ministério da Saúde. Gabinete do Ministro. Portaria $N^{\circ} .158$, de 04 de fevereiro de 2013. Redefine o regulamento técnico de procedimentos hemoterápicos. Diário Oficial da União, Poder Executivo, Brasília, DF, 05 fevereiro 2016. Seção 1, p. 37.

DANTE, L. JR.; DIMAS, T. C. (ed); Padrões para Bancos de Sangue e Serviços de Transfusão. $2^{\mathrm{a}}$ Ed. 2015. 


\section{Anexos}

\subsection{Anexo I - Questionário}

Questionário referente ao Projeto de Mestrado: Custo efetividades das ferramentas de captação, realizado pela Faculdade de Medicina de Ribeirão Preto/USP-FMRP.

Qual das ferramentas abaixo você se sentiu, ou se sentirá, mais estimulado para comparecer em algum hemocentro e realizar a doação de sangue?

* Assinalar no máximo duas alternativas.

\begin{tabular}{|c|c|c|}
\hline Mensagem por E-mail ( & Campanha no Facebook (_ & $\begin{array}{c}\text { Campanha em } \\
\text { Outdoor/letreiros ( }\end{array}$ \\
\hline $\begin{array}{c}\text { Carta para os doadores por } \\
\text { correio }\end{array}$ & Campanha no Instagram & $\begin{array}{l}\text { Carta para os familiares de } \\
\text { pacientes por correio ( }\end{array}$ \\
\hline Mensagem por Celular $({ }(\ldots)$ & Campanha nos canais de TV & Contato por telefone ( \\
\hline
\end{tabular}

Nenhuma das alternativas me convenceria, mas me sentiria convencido a doar sangue se:

Quais destas redes sociais você usa regularmente?

$\square$ Instagram $\quad \square$ Linkedln $\quad \square$ Snapchat $\quad \square$ Messenger $\square$ Google+
$\square$ Twitter $\quad \square$ Pinterest $\quad \square$ Facebook $\square$ Whatsapp $\square$ Youtube




\subsection{Anexo II - Termo de Consentimento Livre e Esclarecido - TCLE}

\section{TERMO DE CONSENTIMENTO LIVRE E ESCLARECIDO}

Título da Pesquisa: "Custo-Efetividade das Ferramentas de captação".

Pesquisadores responsáveis: Edson Zangiacomi Martinez, Professor do Departamento d Medicina Social da Faculdade de Medicina de Ribeirão Preto, Universidade de Săo Paulo (USP), Ribeirão Preto, AV. Bandeirantes, 3900, 14049-900, Ribeiräo Preto/ SP, Telefone: [16] 3602-2569; Leonardo Scalon de Oliveira, aluno de Mestrado Profissional do Curso de Pós-Graduaçăo em Hemoterapia FMRP-USP, telefone (16)99168-4440.

E-mail para contato: Isdeoliveira@gmail.com

Comitê de Ética em Pesquisa: (16) 3602-2220

Esclarecimentos ao participante da pesquisa: $O(\mathbf{a})$ senhor(a) está sendo convidado a participar de uma etapa da pesquisa intitulada "Custo-Efetividade das Ferramentas de Captação", que está sendo desenvolvida por Leonardo Scalon De Oliveira e Edson zangiacomi Martinez. Estamos desenvolvendo uma pesquisa para entender o quanto que as ferramentas de captação de doadores de sangue interferem no convencimento à doaçäo de sangue, identificando a ferramenta mais eficaz. A sua participação neste estudo consiste apenas em responder a um questionário, é totalmente voluntária e ola) senhor(a) poderá deixar de participar e retirar-se do estudo no momento em que desejar, sem qualquer prejuizo. O(a) senhor(a) näo é obrigado(a) a responder a qualquer questão com a qual näo se sinta confortável.

procedimentos do estudo: O(a) senhor(a) foi escolhido(a) para participar do estudo por ser doador voluntário de sangue, de um serviço público de Ribeirão Preto. Convido o(a) senhor(a) apenas a responder algumas perguntas sobre qual é a melhor forma de lhe convidar/convocar para candidatar-se à doação de sangue. 0 tempo estimado para responder ao questionário é| de aproximadamente 2 minutos. Qualquer dúvida que o(a) senhor(a) tiver será esclarecida a qualquer momento, antes ou depois de aceitar o convite para participar da pesquisa.

Riscos e desconfortos: Considera-se que os riscos ao participar do estudo são mínimos, uma vez que pode haver algum constrangimento durante 0 preenchimento do questionário. Lembramos que o(a) senhor(a) não é obrigado a responder a nenhuma pergunta se näo quiser. o preenchimento deste questionário não representa qualquer risco de ordem física. Qualquer sujeito de pesquisa tem direito a indenização conforme as leis vigentes no país, caso ocorra dano decorrente de participação na pesquisa.

Beneficios: Suas respostas são muito importantes para o desenvolvimento desta pesquisa. Ao participar desta pesquisa o(a) senhor(a) não receberá nenhum benefício direto. Não está prevista nenhuma forma de compensaçäo ou remuneraça pela participação no estudo. Entretanto, espera-se que este estudo traga informações importantes para as futuras pesquisas em saúde, dado que ela será bastante importante para entender e identificar qual é a ferramenta que apresenta maior custo efetividade na convocação de doadores de sangue.

Confidencialidade da pesquisa: As informaçôes obtidas serão analisadas apenas pelos pesquisadores responsáveis, Futuramente, os resultados seräo apresentados em congressos e/ou publicados em revistas científicas, ficando garantido que o(a) senhor(a) não será identificado[a], ou seja, seu nome năo será divulgado.

\section{TERMO DE CONSENTIMENTO UIVRE E ESCLARECIDO}

Título da Pesquisa: "Custo-Efetividade das Ferramentas de Captação"

Aceite em participar do estudo: Após estes esclarecimentos, solicito o seu consentimento de forma livre para participar desta pesquisa. Ao assinar este documento, o(a) senhor (a) consente em participar, mas tem a liberdade de sair da pesquisa em qualquer momento. As informaç̧ôes fornecidas pelo(a) senhor(a) săo confidenciais e de conhecimento apenas dos pesquisadores responsáveis. Os sujeitos da pesquisa năo serão identificados em nenhum momento, mesmo quando os resultados desta pesquisa forem divulgados.

Além de poder consultar os pesquisadores para explicaçôes sobre a pesquisa em qualquer momento, o(a) senhor(a) também poderá tirar dúvidas referentes aos aspectos éticos da pesquisa junto ao comitê de ética em Pesquisa do Hospital da clínicas da Faculdade de Medicina de Ribeirão Preto, da Universidade de Säo Paulo, pelo telefone: (16) 3602-2228

Este documento e elaborado em duas vias, devendo uma ficar o(a) senhor[a] e outra com os pesquisadores responsáveis.

Ribeirão Preto de_

Pesquisadora Responsave Leonardo Scalon De Oliveira

Ribeirão Preto de 